Received: 16 March 2017

Accepted: 11 October 2017

Published online: 13 April 2018

NTIFIC REP

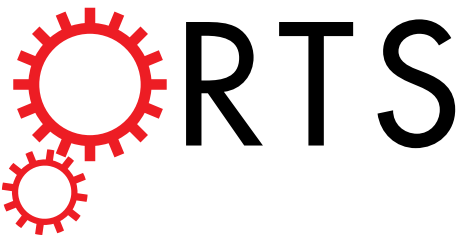

\title{
OPEN Water-stress induced downsizing of light-harvesting antenna complex protects developing rice seedlings from photo-oxidative damage
}

Vijay K. Dalal \& Baishnab C. Tripathy

The impact of water-stress on chloroplast development was studied by applying polyethylene glycol 6000 to the roots of 5-day-old etiolated rice (Oryza sativa) seedlings that were subsequently illuminated up to $72 \mathrm{~h}$. Chloroplast development in drought environment led to down-regulation of light-harvesting Chl-proteins. Photosynthetic proteins of Photosystem II (PSII) and oxygen evolving complex i.e., Cytb559, OEC16, OEC23 and OEC33 as well as those of PSI such as PSI-III, PSI-V, and PSI-VI, decreased in abundance. Consequently, due to reduced light absorption by antennae, the electron transport rates of PSII and PSI decreased by $55 \%$ and $25 \%$ respectively. Further, seedling development in stress condition led to a decline in the ratio of variable $(\mathrm{Fv})$ to maximum $(\mathrm{Fm}) \mathrm{Chl}$ a fluorescence, as well in the quantum yield of PSII photochemistry. Addition of $\mathrm{Mg}^{2+}$ to the thylakoid membranes suggested that $\mathrm{Mg}^{2+}$-induced grana stacking was not affected by water deficit. Proteomic analysis revealed the down-regulation of proteins involved in electron transport and in carbon reduction reactions, and upregulation of antioxidative enzymes. Our results demonstrate that developing seedlings under water deficit could downsize their light-harvesting capacity and components of photosynthetic apparatus to prevent photo-oxidative stress, excess ROS generation and membrane lipid peroxidation.

Abiotic challenges faced by plants are water-stress, salt-stress, high or low temperature-stress, metal-toxicity, nutrient-deprivation and light-stress (for a background on abiotic stress and plants, see Pareek et al. ${ }^{1}$ ). Among these stresses, water-stress (drought) is the most widespread on our Earth. Seedling development, flowering and grain filling are important stages in the life cycle of crop plants, leading to yield losses under stress conditions ${ }^{2}$.

Acclimation responses of mature plants to drought include closure of stomata, hardening of cuticle and cell wall, increased synthesis of osmolytes and antioxidants, altered cell homeostasis and metabolomes, and decreased photosynthesis ${ }^{3,4}$. Photosynthesis is a vital process that is affected by drought, which induces a decrease in the rate of carbon fixation due to reduced photosynthetic electron transport as well as carbon assimilation; this, in turn, results in decreased yield ${ }^{3,5}$. Photosynthetic responses to drought are highly complex; they depend on the intensity and the duration of stress, as well as on the developmental stage of plants.

Carbon assimilation in plants, under water-stress, is mostly affected by lowered $\mathrm{CO}_{2}$ availability, caused by stomatal closure and lower mesophyll conductance ${ }^{6}$, as well as other non-stomatal limitations ${ }^{3,7}$. Miyazawa et al. found that mesophyll conductance during drought is reduced by a disturbance in the functioning of aquaorins, which were involved in $\mathrm{CO}_{2}$ diffusion to the site of carboxylation by Rubisco ${ }^{8}$.

Prolonged exposure of mature well developed plants to water-stress results in decreased carboxylation efficiency of Rubisco and reduction in the activity of various other enzymes of the carbon fixation pathway ${ }^{3,9}$. Physiological, biochemical and proteomic studies have shown that water-stress reduces protein abundance of carbon reduction cycle enzymes, such as Rubisco, Fructose 1,6-bisphosphate aldolase (FBA; EC 4.1.2.13), Sedoheptulose-1, 7-bisphophatase (EC 3.1.3.37), Triose Phosphate Isomerase (TPI; EC 5.3.1.1), and Phosphoglycerate kinase (PGK; EC 2.7.2.3) ${ }^{10-16}$. However, it is interesting to note that in some studies Rubisco content was not severely affected, and photosynthetic $\mathrm{CO}_{2}$ fixation was mostly restored at $\mathrm{Ci}$ equivalent to that under control conditions-as was shown by applying high external $\mathrm{CO}_{2}$ concentrations ${ }^{17-20}$. 
Water-stress is known to affect electron transport from water to NADP. Water-stress has been shown to damage the oxygen-evolving complex of PSII ${ }^{21}$, as well as both the PSII and PSI reaction centers ${ }^{14,22-24}$. Further, $30 \%$ PEG 6000 treatment of mature rice plants results in a reduction of photosynthetic electron transport ${ }^{25}$. Also, water-stress-induced stomatal closure and decreased stomatal conductance limit $\mathrm{CO}_{2}$ availability that results in diverting electrons from the photosynthetic electron transport chain to molecular oxygen generating $\mathrm{ROS}\left(\mathrm{O}_{2}{ }^{-}\right)$ at the end of PS $\mathrm{I}^{26,27}$. At the same time, energy transfer from ${ }^{3} \mathrm{P} 680 *$ (triplet state of PSII reaction center chlorophyll $a$, in its excited state) and even from antenna chlorophylls (Chl), in their triplet state, to oxygen generates singlet oxygen $\left({ }^{1} \mathrm{O}_{2}\right)$ that often damages thylakoid membranes ${ }^{27-31}$.

Rice seeds germinate beneath the soil and the seedlings grow in near-darkness till they emerge to the surface (skotomorphogenesis). During skotomorphogenesis, seedlings do not synthesize Chl, since the Chl biosynthesis pathway enzyme protochlorophyllide oxidoreductase (POR) (EC 1.3.33.1) requires light to photo-transform Pchlide to Chlide ${ }^{32}$. Therefore, in rice, the differentiation of etioplast to chloroplast does not take place in darkness. Upon exposure to light, as the seedlings grow, Chl biosynthesis and the associated greening process transform the etioplasts into chloroplasts ${ }^{33}$. These developing seedlings are very often exposed to drought, due to scarcity of rainfall. These developing seedlings are able to withstand water-stress for a long time ${ }^{2}$ and rebound upon rain fall. Therefore, it is important to understand its underlying mechanism of tolerance to water-stress.

Photosynthetic responses of mature plants and developing greening seedlings to water-stress are fundamentally different. In mature leaves, functional photosynthetic complexes are already formed and water-stress induces generation of ROS due to excess light absorption, which affect the photosynthetic apparatus. However, in water-stressed developing seedlings, there is the possibility to down-regulate Chl biosynthesis and downsize the synthesis and assembly of light-harvesting complexes of PSI and PSII, and to adapt plants not to absorb excess light, which is harmful. In our previous study ${ }^{33}$, we have shown that PEG-induced water-stress during early rice seedling development minimizes $\mathrm{Chl}$ biosynthesis. Active photosynthesis complexes are formed by the assembly of apo-proteins and incoporation of chlorophyll in them ${ }^{34}$. Therefore, reduced Chl synthesis in water-stressed developing seedlings is likely to affect chloroplast biogenesis. PEG-6000 has long been utilized as a reliable osmoticum for the simulation and constitutive maintenance of water-stress in plants under laboratory conditions, due to its property to act as a non-penetrating osmotic agent that decreases water potential of the cells $^{35,36}$. To understand the mechanism of relative tolerance of developing seedling to drought, we have studied the impact of water-stress on the photosynthetic apparatus during early seedling growth, as they emerge from skotomorphogenesis beneath the soil to photomorphogenesis stage above the soil.

\section{Results}

To understand the impact of water-stress on chloroplast biogenesis during the early photomorphogenesis, 5-d-old etiolated rice seedlings were treated with polyethylene glycol (PEG 6000) for 16 hours prior to their transfer to continuous cool-white fluorescent (plus incandescent) light $\left(100 \mu \mathrm{mol}\right.$ photons $\left.\mathrm{m}^{-2} \mathrm{~s}^{-1}\right)$. In this paper, we have analyzed the structure and function of chloroplasts, ROS production, and associated processes to assess the role of water-stress on early seedling development.

Impact of Water-Stress on Chloroplast Development. Chl a fluorescence measurements. Fo, Fm and $\mathrm{Fv} / \mathrm{Fm}$ ratio were monitored after water-stress treatment of etiolated rice seedlings for $72 \mathrm{~h}$ with $40 \mathrm{mM}$ and 50 $\mathrm{mM}$ PEG, in the presence of light $\left(100 \mu \mathrm{mol}\right.$ photons $\left.\mathrm{m}^{-2} \mathrm{~s}^{-1}\right)$. Seedlings were kept for $20 \mathrm{~min}$ in darkness (see Materials and Methods) before the initial (Fo), and the maximum (Fm), fluorescence was measured. The minimum fluorescence Fo decreased by $11 \%$ and $21 \%$ in the seedlings treated with 40 and $50 \mathrm{mM}$ PEG compared to the controls, while Fm decreased by $32 \%$ and $63 \%$ respectively (see Fig. 1A).

The ratio $\mathrm{Fv} / \mathrm{Fm}=(\mathrm{Fm}-\mathrm{Fo}) / \mathrm{Fm}$, a "proxy" of the maximum quantum yield of PSII photochemistry ${ }^{37}$, declined in water-stressed samples; Fv/Fm calculated after $72 \mathrm{~h}$ of greening decreased by $10 \%$ and $22 \%$ in 40 and $50 \mathrm{mM}$ PEG-treated seedlings (Fig. 1A).

Quantum yield of PSII ( $\phi P S I I)$ and non-photochemical quenching (NPQ) during $300 \mathrm{~s}$ illumination with actinic light. As expected, $\phi$ PSII declined at higher light intensity. Compared to the controls, $\phi$ PSII, at the highest light intensity $\left(\sim 275 \mu \mathrm{mol}\right.$ photons $\left.\mathrm{m}^{-2} \mathrm{~s}^{-1}\right)$, was reduced by $33 \%$ and $58 \%$ in samples treated with $40 \mathrm{mM}$ and $50 \mathrm{mM}$ PEG (Fig. 1B). On the other hand, the NPQ ((Fm - Fm $\left.\left.{ }^{\prime}\right) / \mathrm{Fm}^{\prime}\right)$ increased in response to increase in light intensity. It was higher in $40 \mathrm{mM}$ and $50 \mathrm{mM}$ PEG-treated seedlings than in controls by $21 \%$ and $29 \%$ under the highest $\left(\sim 275 \mu \mathrm{mol}\right.$ photons $\left.\mathrm{m}^{-2} \mathrm{~s}^{-1}\right)$ light intensity used (Fig. 1C).

Room temperature (298K) Chl a fluorescence spectra. Chl a fluorescence emission spectrum of thylakoid membranes isolated (after $72 \mathrm{~h}$ greening) had a peak at $684 \mathrm{~nm}$; this is mostly, from PSII antenna ${ }^{38}$. Upon the addition of $\mathrm{Mg}^{2+}$ in the suspension medium, this peak increased in the control as well as in the water-stressed samples (Fig. 2A). In water-stressed samples, the fluorescence intensity at $684 \mathrm{~nm}$ was substantially lower both in the presence and the absence of $\mathrm{Mg}^{2+}$, compared to the controls.

Low temperature Chl a fluorescence spectra. Low temperature (77 K) fluorescence emission spectra monitored after $72 \mathrm{~h}$ of light exposure are shown in Fig. 2B. Thylakoid membranes of control samples, suspended in a low salt medium $\left(0 \mathrm{mM} \mathrm{Mg}^{2+}\right)$, had a peak at $686 \mathrm{~nm}$ due to PSII and at $740 \mathrm{~nm}$ due to PSI ${ }^{38}$; usually, PSII shows two emission bands at $\sim 684 \mathrm{~nm}$ (from light- harvesting complex) and at $695 \mathrm{~nm}$ (from CP47), although a single peak has been observed in some cases (e.g. in Gonyaulax polyedra) ${ }^{39}$. Fluorescence emission spectra, shown here, were normalized at $686 \mathrm{~nm}$. In water-stressed samples, the emission peak of PSI shifted from $740 \mathrm{~nm}$ to $738 \mathrm{~nm}$. Upon addition of $\mathrm{Mg}^{2+}(4 \mathrm{mM})$, the PSI fluorescence emission at $740 \mathrm{~nm}$ (normalized at $686 \mathrm{~nm}$; PSII) decreased in both the control and the water-stressed samples. 
A

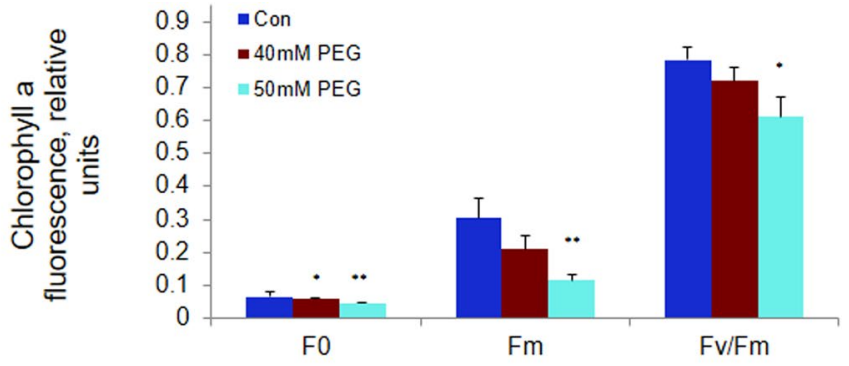

B
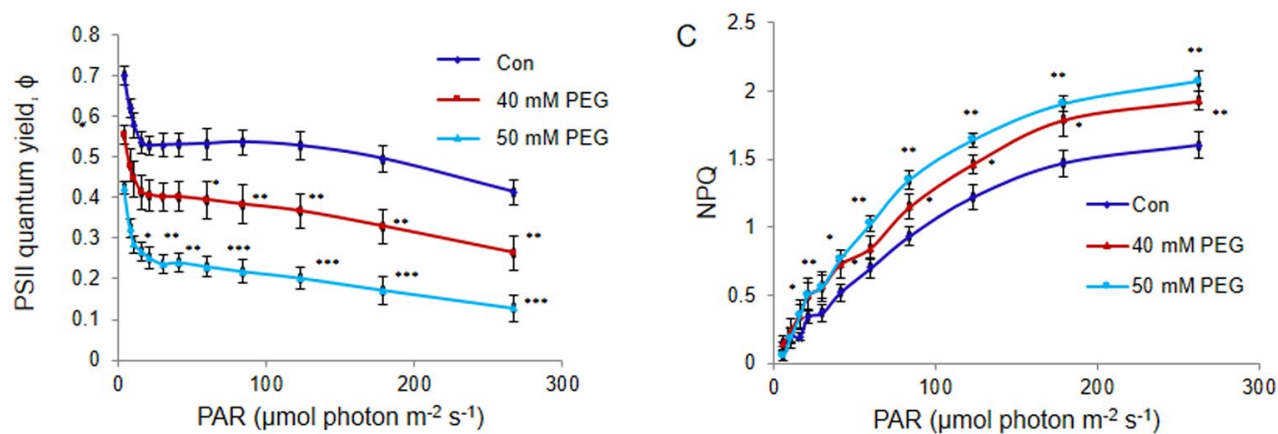

Figure 1. Chlorophyll $a$ fluorescence measurements of control and water-stressed rice seedlings after 72 $\mathrm{h}$ of greening. (A) Fo, Fm, Fv/Fm $=(\mathrm{Fm}-\mathrm{Fo}) / \mathrm{Fm},(\mathbf{B})$ "Operating" quantum yield $(\Phi)$ of PSII and $(\mathbf{C})$ Non-photochemical quenching (NPQ). Five-day old etiolated seedlings were treated with $40 \mathrm{mM}$ (or 50 $\mathrm{mM}$ ) PEG 6000 dissolved in half strength MS nutrient soln., $16 \mathrm{~h}$ prior to their illumination with cool white fluorescent + incandescent light $\left(100 \mu \mathrm{mol}\right.$ photons $\left.\mathrm{m}^{-2} \mathrm{~s}^{-1}\right)$, at $28^{\circ} \mathrm{C}$. Chl $a$ fluorescence based parameters were measured with a PAM 2100 fluorometer. "Operating" PSII quantum yield $(\Phi)$ and NPQ were calculated as $\left(\mathrm{Fm}^{\prime}-\mathrm{Ft}\right) / \mathrm{Fm}^{\prime}$ and $\left(\mathrm{Fm}-\mathrm{Fm}^{\prime}\right) / \mathrm{Fm}^{\prime}$ respectively. Each data point is the average of three replicates. The error bars represent standard deviations (SD). ANOVA: $* p<0.05 ; * p<0.01$; and $* * * p<0.001$.
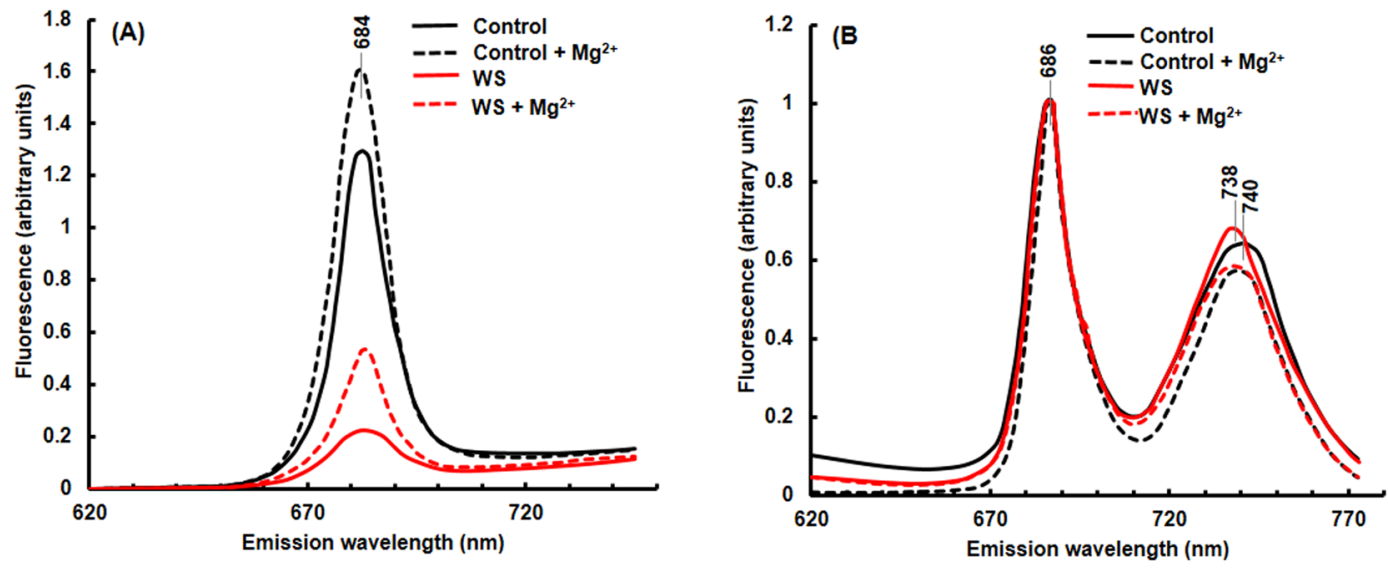

Figure 2. Fluorescence emission spectra of thylakoid membranes isolated from leaves of control and waterstressed rice seedlings. (A) Room temperature and (B) Low temperature (77K) fluorescence spectra (E440) of thylakoid membranes ( $3 \mu \mathrm{g} \mathrm{Chl}$ ) suspended in $5 \mathrm{mM}$ Hepes- $\mathrm{NaOH}$ buffer containing 0 or $4 \mathrm{mM} \mathrm{MgCl} 2$ ( $\mathrm{pH} 7.5$ ), after $72 \mathrm{~h}$ of stress treatment. Seedlings were treated as in Fig. 1. Fluorescence emission spectra were recorded in ratio mode in a photon counting SLM-AMINCO 8000 spectrofluorometer. For $77 \mathrm{~K}$ spectral measurements, excitation and emission slit widths were set at $4 \mathrm{~nm}$. For room temperature spectra, the excitation and emission slit widths were set at $8 \mathrm{~nm}$ and $4 \mathrm{~nm}$, respectively. The room temperature spectra were corrected for photomultiplier tube response. Rhodamine B was used in the reference channel as a quantum counter. A tetraphenylbutadiene (TPD) block was used to adjust the voltage to 20000 counts per second in the sample as well as in the reference channels at excitation and emission wavelengths of $348 \mathrm{~nm}$ and $422 \mathrm{~nm}$, respectively. Fluorescence spectra were measured three times and identical results were obtained. 

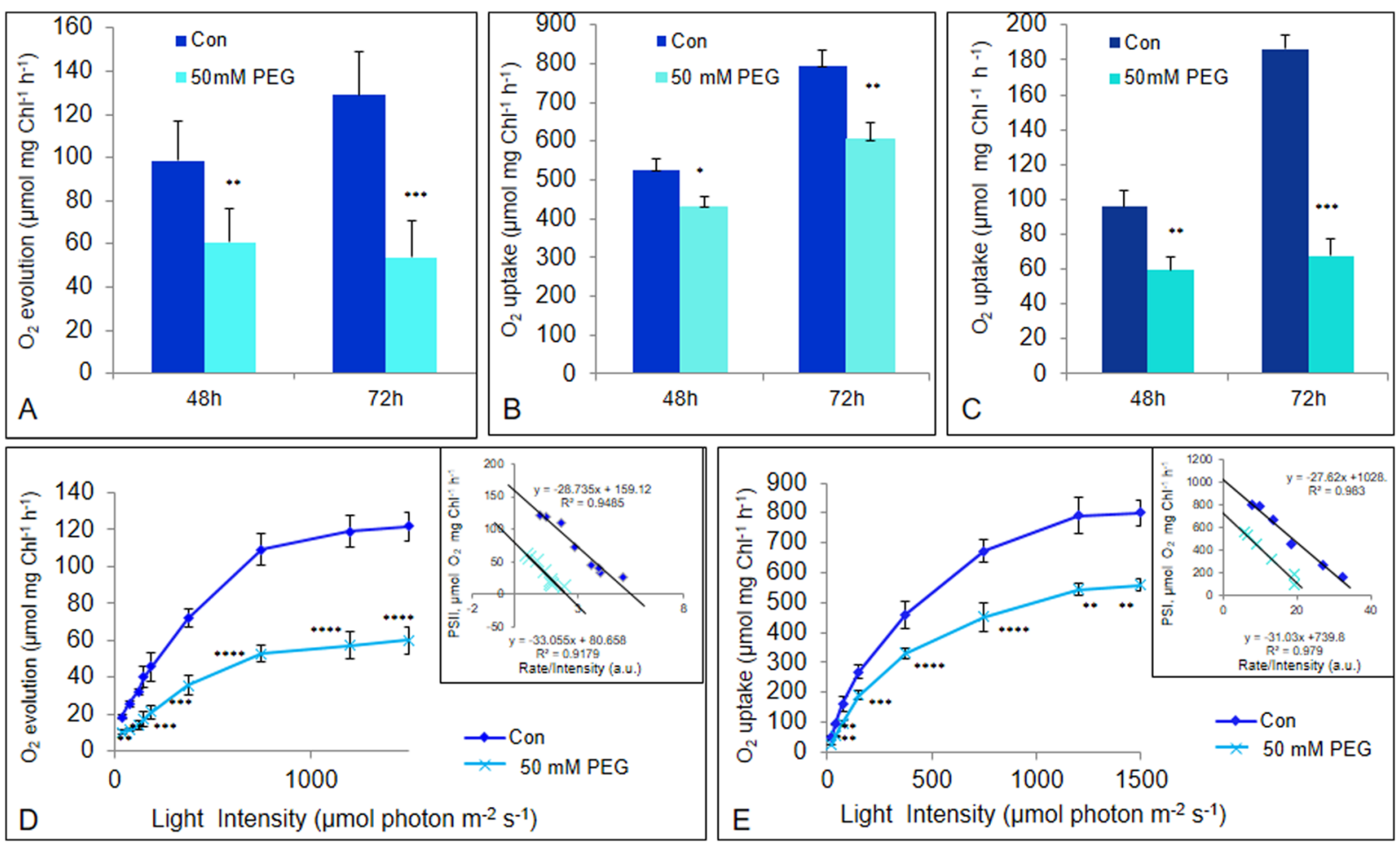

Figure 3. Photosynthetic polarographic measurements of thylakoid membranes isolated from control and water-stressed rice seedlings. (A) PSII, (B) PSI and (C) whole chain activities after $48 \mathrm{~h}$ and $72 \mathrm{~h}$ of greening, and light saturation curve of (D) PSII and (E) PSI reactions after $72 \mathrm{~h}$ of greening in thylakoid membranes isolated from control and water-stressed seedlings. Seedlings were treated essentially as in Fig. 1. Oxygen evolution/uptake by thylakoid membranes was measured by Oxy Lab, Hansatech. Thylakoids, equivalent to 20 $\mu \mathrm{g}$ of Chl, were used for each reaction. PSII, PSI and whole chain activities were measured as electron transport from $\mathrm{H}_{2} \mathrm{O}$ to p-phenylenediamine (PD), Ascorbate/DCIP couple to methylviologen (MV) and $\mathrm{H}_{2} \mathrm{O}$ to $\mathrm{MV}$, respectively. For measurement of light saturation curve, different light intensities were obtained from a tungsten lamp using neutral density filters. Each data point is the average of three replicates. The error bars represent SD. ANOVA: $* p<0.05 ; * * p<0.01$; and $* * * p<0.001$.

PSII, PSI and the whole chain electron transport in isolated thylakoid membranes. To probe further results obtained from Chl $a$ fluorescence measurements, we monitored partial PSII and PSI electron transport reactions, as well as the whole photosynthetic electron transport chain in thylakoid membranes isolated from control and water-stressed seedlings.

PSII activity. The partial PSII electron transport, which was measured polarographically as light-driven electron transport from $\mathrm{H}_{2} \mathrm{O}$ to phenylenediamine, increased as the greening process of etiolated control seedlings progressed (Fig. 3A). Further, in $50 \mathrm{mM}$ PEG-treated seedlings, PSII activity was reduced by $35 \%$ and $55 \%$ after $48 \mathrm{~h}$ and $72 \mathrm{~h}$ of greening compared to that in the controls.

PSI activity. The partial PSI electron transport, which was measured polarographically as light-driven electron transport from ascorbate/DCIP to methylviologen, increased in response to chloroplast development during light exposure. Similar to PSII, PSI electron transport decreased in water-stressed seedlings, compared to controls, but to a lower extent than that of PSII: i.e., by $20 \%$ and $25 \%$ after $48 \mathrm{~h}$ and $72 \mathrm{~h}$ of chloroplast biogenesis (Fig. $3 \mathrm{~B}$ ).

The whole (photosynthetic) electron transport chain. The whole chain electron transport through PSII and PSI, which was measured polarographically as light-driven electron transport from $\mathrm{H}_{2} \mathrm{O}$ to methylviologen, was reduced by $35 \%$ after $48 \mathrm{~h}$ and $65 \%$ after $72 \mathrm{~h}$ of greening in stressed seedlings compared to control (Fig. 3C).

Light saturation curves of PSII and PSI electron transport reactions. PSII. To further ascertain if the inhibition of PSII reaction was due to reduction in the quantum yield of PSII photochemistry measured in limiting light intensities or it was in light saturated electron transport, we measured the rate of PSII reaction as a function of different light intensities, using thylakoid membranes isolated from the control as well as from water-stressed seedlings, after $72 \mathrm{~h}$ of greening. The dependence of PSII activity on light intensity showed typical saturation kinetics (Fig. 3D). Both the initial slope at limiting light intensities as well as light-saturated electron transport, were affected in PEG-treated seedlings. As compared to the control thylakoids, the percent inhibition of PSII reaction in water-stressed thylakoids was almost constant (nearly 50\%) at all the light intensities used 
(A)

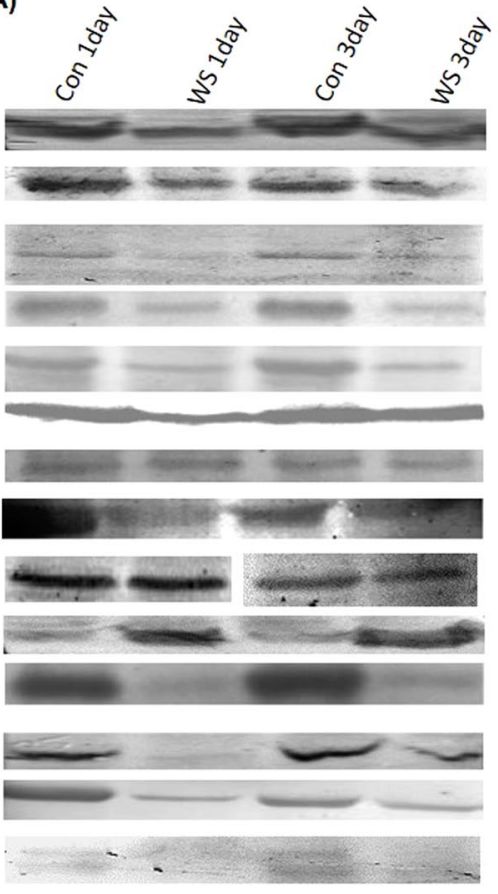

(B)

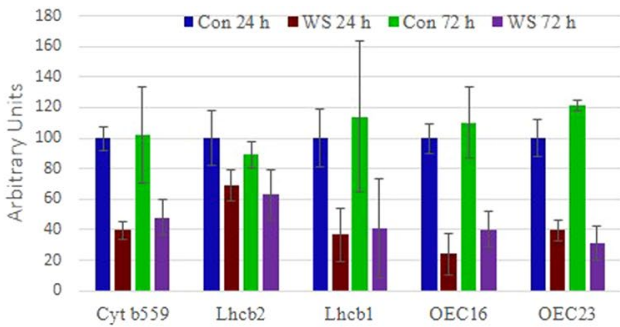

OEC16

OEC23

OEC33

Cyt $f$

Cyt b/f Subunit IV

PSI sub III/PsaF

PSI sub IV/ PsaE

PSI sub V/PsaK

PSI sub VI/ PsaH

Lhc a1

Lhc a4

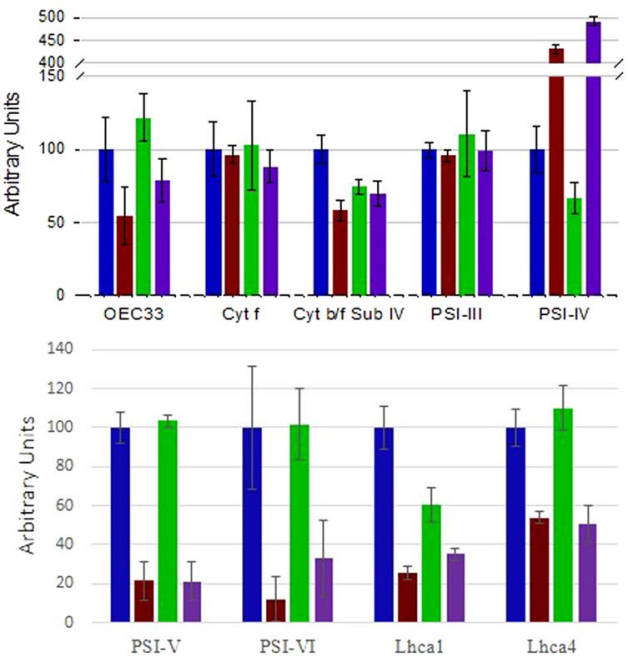

Figure 4. Immunoblot analysis of photosynthetic proteins. (A) Immunoblot and (B) Quantitation of immunoblots; Seedlings were treated as described in Fig. 1. Thylakoid membranes were isolated from control and water-stressed rice seedlings after $24 \mathrm{~h}$ and $72 \mathrm{~h}$ of greening. Equal amount of protein $(20 \mu \mathrm{g})$ was separated on $12.5 \%$ SDS-PAGE. After transfer to nitrocellulose membranes, the blotted bands were immune-detected with specific antibodies for each protein and subsequently visualized utilizing alkaline phosphatase labeled anti-IgG antibodies. Quantitation of immunoblots was performed with ImageJ and is represented as percent of control ( $24 \mathrm{~h}$ ) values. In immunoblot image of PSI sub III, intervening lines have been removed (white gap). Error bars represent SD of three independent replicates.

(Fig. 3D). The Eadie plot (i.e., the rate of oxygen evolution $v s$ rate of oxygen evolution/light intensity in terms of $\%$ saturation ${ }^{40}$ showed a straight line characterized by the equation $y=-28.73 x+159.1\left(R^{2}=0.948\right)$ for the control seedlings and $y=-33.05 x+80.65\left(R^{2}=0.917\right)$ for the water-stressed seedlings (insets in Fig. 3D). Both the intercepts on the abscissa and on the ordinate were reduced by nearly $50 \%$.

PSI. In the PSI case, both the initial slope of electron transport rate at limiting light intensity as well as high light intensity i.e., for saturated electron transport rate, were reduced almost equally by $\sim 30 \%$ (Fig. 3E). The Eadie plot showed a straight line with an equation $\mathrm{y}=-27.62 \mathrm{x}+1028\left(\mathrm{R}^{2}=0.983\right)$ for the control seedlings and $y=-31.03 x+739.8\left(R^{2}=0.979\right)$ for the water-stressed seedlings (inset Fig. 3E). Intercepts on the abscissa and on the ordinates were reduced by nearly $30 \%$.

Immunoblot analysis of photosynthetic proteins. To understand the mechanism of water-stress induced down-regulation of photosynthesis during the development of the photosynthetic apparatus in the rice seedlings, we performed immunoblot analysis of proteins involved in PSII, PSI and the inter-system electron transfer.

PSII. Most of proteins/pigment-protein complexes of PSII increased upon illumination of the seedlings. The abundance of cyt b559, an intrinsic membrane protein intimately associated with PSII reaction center, declined by $58 \%$ and $52 \%$ from that in the controls, in the developing rice seedlings after 24 and $72 \mathrm{~h}$ of water-stress treatment (Fig. 4). Further, light-harvesting pigment-protein complexes associated with PSII i.e., Lhcb2 and Lhcb1, were reduced by $30 \%$ and $63.4 \%$ after $24 \mathrm{~h}$ of water-stress treatment, and by $30 \%$ and $64 \%$ after $72 \mathrm{~h}$ treatment (Fig. 4 ).

Oxygen Evolving Complex, OEC. Most of the oxygen evolving complex proteins were severely reduced in the rice seedlings subjected to water-stress during chloroplast development. The OEC16 and OEC23 were reduced by $~ 75 \%$ and $66 \%$ respectively in water-stressed seedlings (Fig. 4 ) after $24 \mathrm{~h}$ of stress. Similarly, at this time point, other major OEC protein i.e., OEC33 was reduced by $\sim 50 \%$ (Fig. 4). 
$24 \mathrm{~h}$
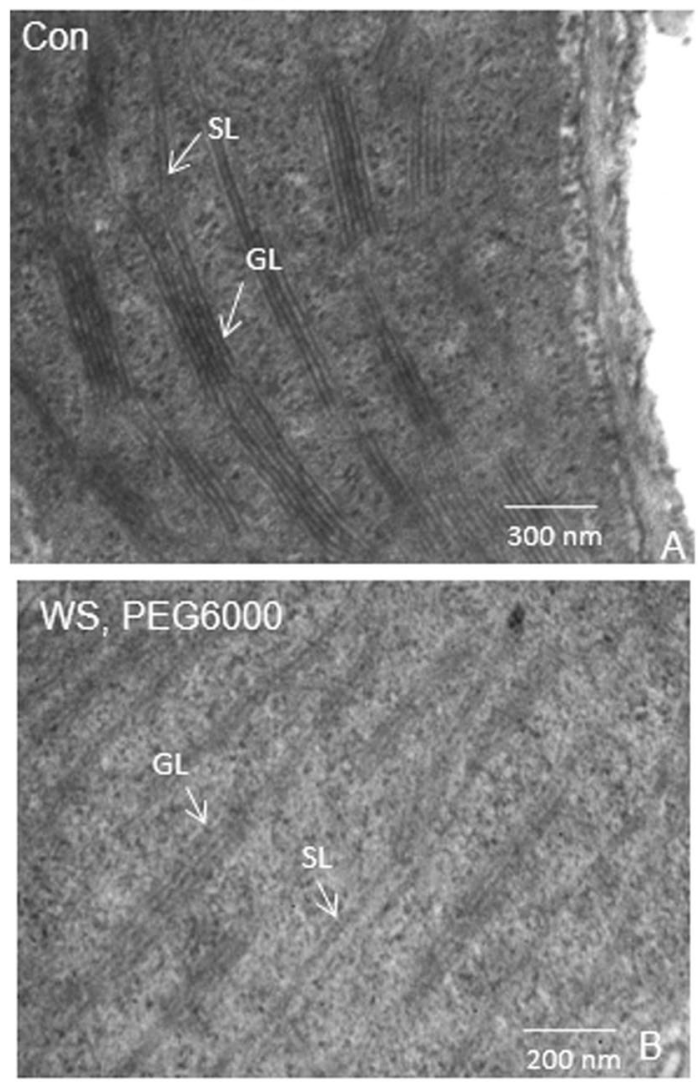

$72 \mathrm{~h}$
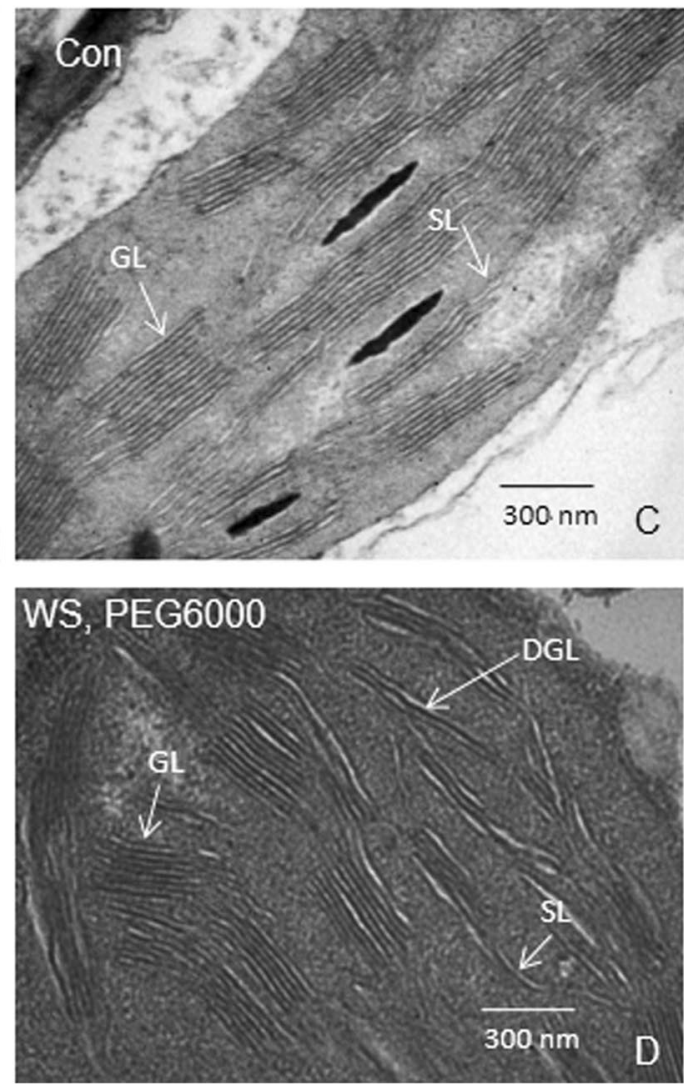

Figure 5. Ultrastructure of chloroplasts. Transmission electron micrograph depicting the ultrastructure of chloroplast was performed in control and water-stressed rice seedlings, after (A and B) $24 \mathrm{~h}$ and (C and D) 72 $\mathrm{h}$ of greening. Seedlings were treated as described in Fig. 1. Glutaraldehyde fixed tissues were dehydrated with acetone, cleared with epoxy propane or xylene and infiltrated with araldite. Araldite was polymerized at $50{ }^{\circ} \mathrm{C}$ for $12-24 \mathrm{~h}$ and then at $60^{\circ} \mathrm{C}$ for $24-48 \mathrm{~h}$. Ultrathin sections were cut, stained in saturated uranyl acetate in $50 \%$ ethanol for 10-15 min, washed in 50\% ethanol and distilled water, and viewed in a Transmission Electron Microscope. The electron micrograph of chloroplasts were performed three times and representative figures are displayed. Scale bar is $200 / 300 \mathrm{~nm}$. GL-grana lamellae, SL-stroma lamellae, DGL-dis-integrated grana lamellae.

Cytochrome $b_{6} / f$. The protein abundance of cyt $\mathrm{f}$, as well as the subunit IV of $\mathrm{cyt}_{\mathrm{t}} \mathrm{b}_{6} / \mathrm{f}$ complex declined by $4 \%$ and $15 \%$, and by $40 \%$ and $7 \%$ after $24 \mathrm{~h}$ and $72 \mathrm{~h}$ of water-stress respectively during chloroplast biogenesis (Fig. 4).

PSI. In water-stressed seedlings, the protein abundance of the PSI subunit III (PsaF, $22 \mathrm{kD}$ ) was reduced by $\sim 5 \%$, while protein expression of the subunit V (PsaK, $17 \mathrm{kD}$ ) was severely reduced by $\sim 80 \%$ after $24 \mathrm{~h} / 72 \mathrm{~h}$ treatment (Fig. 4). Further, the PSI subunit VI (PsaH, $11 \mathrm{kD}$ ) was reduced by $88 \%$ and $67 \%$, due to $24 \mathrm{~h}$ and $72 \mathrm{~h}$ water-stress. In contrast, PSI subunit IV (PsaE, $11 \mathrm{kD}$ ) had increased by 4 and 5 fold in water-stressed seedlings (Fig. 4). The PSI antenna proteins Lhcal and Lhca 4 were reduced by $75 \%$ and $46 \%$ after 24 h of water-stress treatment, and by $42 \%$ and $55 \%$ in seedlings water-stressed for $72 \mathrm{~h}$.

Ultrastructure of chloroplast thylakoids. After 24-72 h of greening, both thylakoids and grana were well developed and contained starch granules in control samples. However, chloroplasts in the water-stressed seedlings had swollen thylakoids, disintegrated granal organization (mostly after $72 \mathrm{~h}$ ) and fewer starch granules (Fig. 5).

$\mathrm{H}_{2} \mathrm{O}_{2}$ content. $\mathrm{H}_{2} \mathrm{O}_{2}$ content remained approximately the same in both water-stressed and the control rice seedlings, after $24 \mathrm{~h}$ of greening (Fig. 6A); however, after $72 \mathrm{~h}$ of greening, $\mathrm{H}_{2} \mathrm{O}_{2}$ content increased by $23 \%$ as compared to control samples.

Malondialdehyde (MDA) content. Thiobarbituric acid reactive substances (TBARS)/MDA equivalent production is an index of membrane lipid peroxidation ${ }^{41}$. Since there was similar amount of $\mathrm{H}_{2} \mathrm{O}_{2}$ production in both the control and water-stressed seedlings (after $24 \mathrm{~h}$ of greening), we did not observe any significant increase in MDA content either. After $72 \mathrm{~h}$ of greening under water-stress, the MDA content increased by $50 \%$ above the control value, as expected (Fig. 6B). 
A

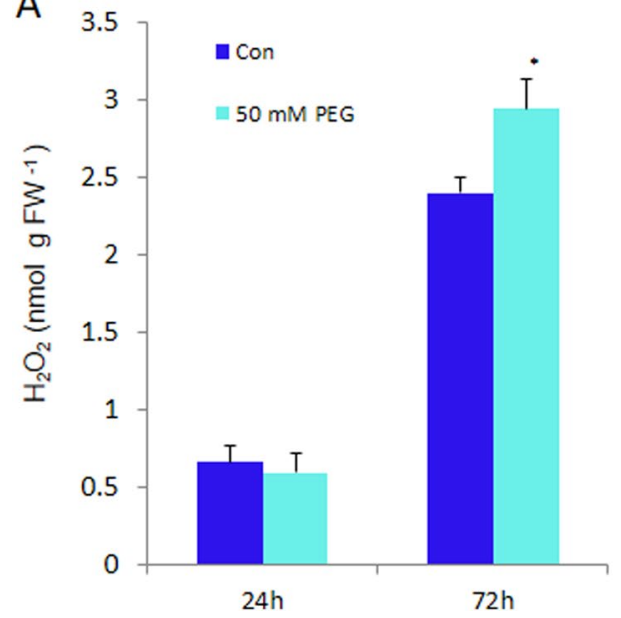

B

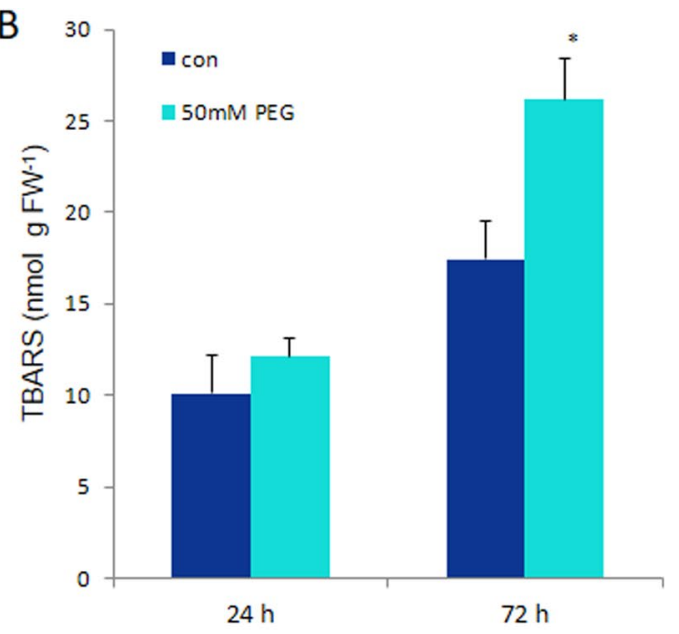

Figure 6. Antioxidative response of seedlings. (A) $\mathrm{H}_{2} \mathrm{O}_{2}$ content and (B) MDA content in control (Con) and stressed (50 mM PEG) rice seedlings after $24 \mathrm{~h}$ and $72 \mathrm{~h}$ of greening. Seedlings were treated as in Fig. 1. $\mathrm{H}_{2} \mathrm{O}_{2}$ was measured by absorbance at $240 \mathrm{~nm}$, against a standard curve and MDA was measured as TBARS equivalents. Leaf tissue $(200 \mathrm{mg}$ ) was homogenized in $20 \%$ TCA solution with and without $0.25 \%$ TBA, boiled and centrifuged. Absorptions at 440, 532 and $600 \mathrm{~nm}$ were measured from supernatant. Unspecific absorption contribution from without-TBA solution was deducted appropriately (see $M \& M$ ) from sample values. The error bar represents SD of three replicates. ANOVA: $* p<0.05 ; * p<0.01$; and $* * * p<0.001$.

A

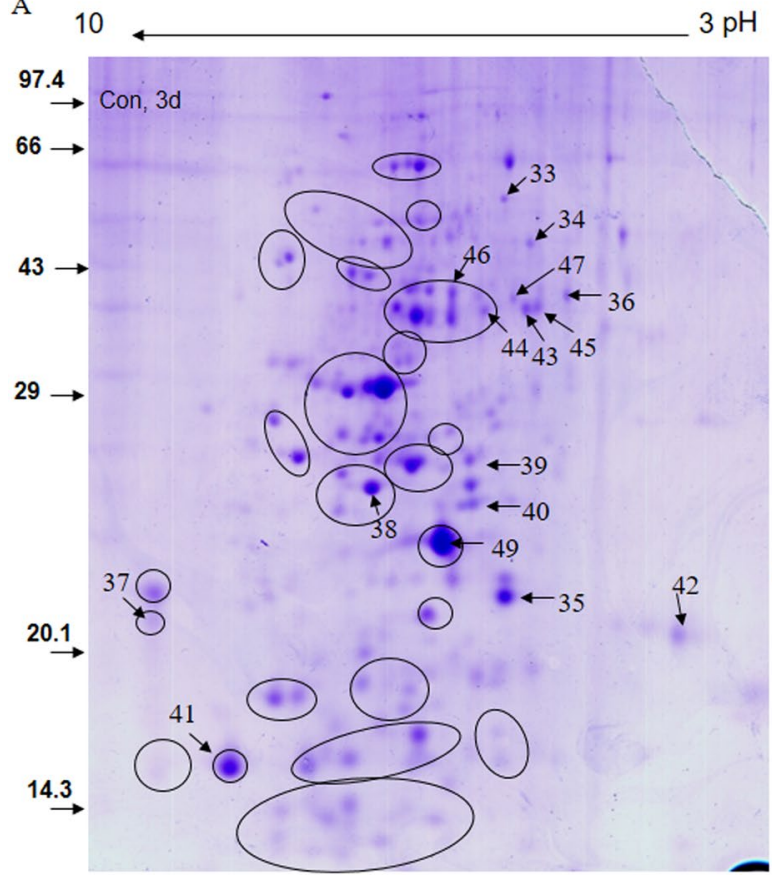

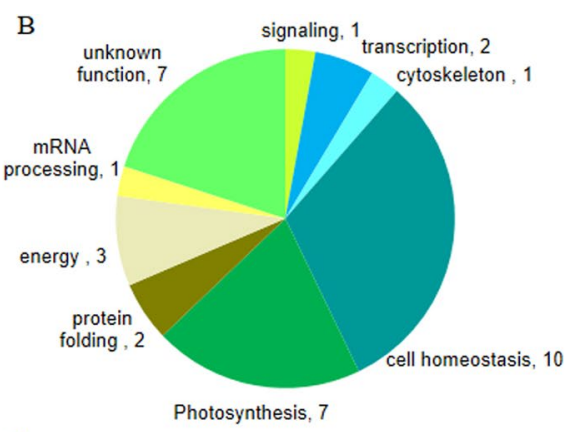

C

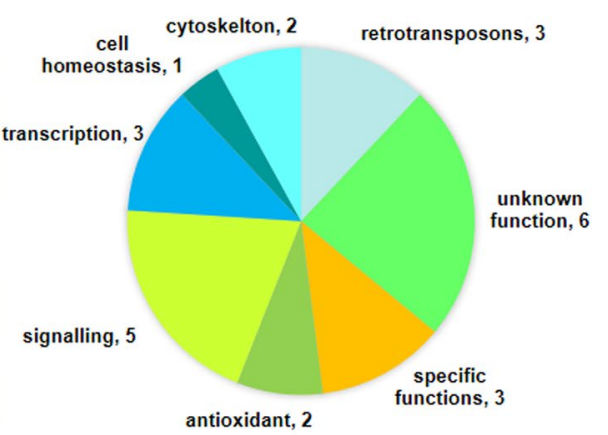

Figure 7. Proteomics of PEG fractionated soluble and peripheral thylakoid proteins of rice leaves after 72 $\mathrm{h}$ of water-stress treatment in light. Five-day old etiolated seedlings were subject to water-stress as in Fig. 1. The 2D gel of control and treated samples were done several times till a consistent pattern was obtained. (A) Representative 2-D gel of PEG fractionated soluble proteins of control rice seedlings, (B) functional category distribution of 34 down-regulated and (C) 25 up-regulated differentially expressed proteins based on actual number of identified proteins. Soluble proteome was isolated and PEG fractionated in two steps; first upto $10 \%$ and later upto $20 \%$ to remove abundant proteins e.g. Rubisco. Protein $(800 \mu \mathrm{g})$ from supernatant was treated with G-Biosciences Perfect Focus kit to remove impurities; the obtained pellet was air dried and dissolved in rehydration buffer. After rehydration, isoelectric focusing of proteins was done on a $17 \mathrm{~cm} \mathrm{IP}$ strip overnight; strip was equilibrated and second dimension was run on a 12.5\% SDS-PAGE. 2-D gel was stained with Coomassie Brilliant Blue (CBB), Imaged with UMAX PowerLook 2100XL Image Scanner. Spots were detected, and matched with the Image Master-2D Platinum 6.0 software to get differentially expressed proteins. Numbered spots showing down-regulated proteins in the representative gel from control seedlings are mentioned in text and tables starting with CBC3. 
Differentially expressed proteins. Soluble and peripheral membrane proteome was analyzed by 2-D gel electrophoresis and MALDI-TOF/TOF or ESI-MS/MS analysis of spots, after $72 \mathrm{~h}$ of greening. Silver-staining as well as colloidal Coomassie Brilliant Blue (CBB)-staining was used to visualize the spots (Fig. 7A). In silver-stained gel, we identified 31 differentially expressed proteins; 10 were up-regulated and 21 were down-regulated. In CBB-stained gels, we further identified 15 up-regulated and 13 down-regulated proteins. In total, 34 down-regulated proteins and 25 up-regulated proteins were identified (Table 1): Silver-stained proteins are named starting with 'SS', and CBB-stained spots are named staring with 'CB'; C3 and W3 denote spots from the 'control' and the 'water-stressed' samples, respectively, after $72 \mathrm{~h} / 3 \mathrm{~d}$ of greening. Gene Annotations, Gene Index (GI) number, locus names, gene names and localization (wherever known or predicted) for identified proteins are provided in the Supplementary Table S1. Out of 59 differentially expressed identified proteins, for 18 Uniprot IDs, no gene models were retrieved from the rice database (http://ricedb.plantenergy.uwa.edu. $\mathrm{au} /$ ). For the remaining 41 (59-18) Uniprot IDs, 56 corresponding gene-model/loci were retrieved as shown in the Supplementary Table S1. GO enrichment analysis performed using loci given in Supplementary Table S3, is provided in the Supplementary Table S2. Enriched GO-terms (Biological Process) $(\mathrm{p}<0.05)$ were glycolysis, tricarboxlic acid cycle, cellular carbohydrate metabolic process, oxidation-reduction, cysteine biosynthetic process, photosystem II stabilization, carbon fixation, hydrogen peroxide catabolic process, cysteine biosynthetic process from serine, phosphatidyl inositol metabolic process and phosphate metabolic process.

Category-wise distribution of down-regulated and up-regulated identified proteins is presented in Fig. 7A and B respectively. Differentially-regulated proteins were functionally distributed into 12 groups (Table 1).

Down-regulated proteins (Table 1, and Supplementary Table S1) were categorized into 9 groups (Fig. 7A), namely: (i) photosynthesis ("light reaction"; OEC23, OEC33 and carbon fixation; Rubisco LSU, FBA, PGK, TPI); (ii) protein folding and degradation (PPIase and Lon protease); (iii) energy balance (putative ATP synthase $\delta$ subunit; inorganic pyrophosphatase and mitochondrial formate dehydrogenase precursor); (iv) transcription/ RNA stabilization (mTERF and CSD protein); (v) cytoskeleton organization (similar to WD40 domain containing and kinesin like); (vi) cell homeostasis (Cyt P450 protein, TRX domain containing protein, cysteine synthase 1, glycerol 3-phosphate dehydrogenase (GPDH), malate dehydrogenase ( $\mathrm{MDH})$, aminotransferase like and anion transporting protein); (vii) mRNA processing (UPF0614 protein C14orf102); (viii) signaling; and (ix) unknown/ uncharacterized proteins.

The proteins that were up-regulated (Table 1 and Supplementary Table S1) in water-stressed seedlings were distributed into 8 categories (Fig. 7B), which are: (i) signaling (receptor like kinase, putative receptor kinase, phosphatidyl inositol 4-phosphate 5-kinase 4 (PIP5K4), calcineurin-like phosphoesterase like, $\mathrm{Ca}^{2+}$ binding EF hand-5 domain containing); (ii) transcription/RNA stabilization $\left(\mathrm{C}_{2} \mathrm{H}_{2} \mathrm{Zn}\right.$-Finger, $\mathrm{C}_{3} \mathrm{H} \mathrm{Zn}$ finger, RNA binding protein); (iii) retrotransposons (Ty-1 copia type; putative gag pol polymerase and plant disease resistance polyprotein-like retrotransposon); (iv) antioxidant defense mechanism (ascorbate peroxidase (APx1), and dehydro ascorbate reductase (DHAR)); (v) cytoskeleton organization (Kinesin heavy chain like and Glucosyl-galactosyl transferase); (vi) cell homeostasis (Cyt P450); (vii) specific functions (SalT; IAA amino acid hydrolase ILR1-like 3); and (viii) uncharacterized proteins.

\section{Discussion}

During photomorphogenesis, Chl, proteins, and lipids are synthesized and assembled to form the functional photosynthetic apparatus. Earlier, Dalal and Tripathy ${ }^{33}$ showed that water-stress during transition from skotomorphogenesis to photomorphogenesis led to a $42 \%$ reduction in Chl content, due to down-regulation of expression of genes and proteins involved in Chl biosynthesis ${ }^{33}$. This must be, at least partly, responsible for the lower Fo and Fm (Fig. 1A), as well as the lower Chl a fluorescence in water-stressed rice seedlings (Fig. 4A). Shibata shift (blue shift of absorption maximum of chlorophyllide from $684 \mathrm{~nm}$ (aggregated form) to $672 \mathrm{~nm}$ (disaggregated form), discovered by K. Shibata ${ }^{42}$ that takes place within a few minutes of light exposure of etiolated seedlings was also impaired in stressed seedlings ${ }^{33}$. In higher plants, both $\mathrm{Chl} a$ and $\mathrm{Chl} b$ are bound to light-harvesting pigment-protein complexes, LHCs. The availability of $\mathrm{Chl} b$ is essential for the assembly and functioning of most LHC proteins ${ }^{43}$. Binding of Chls to the LHC proteins stabilizes the latter in the thylakoid membranes ${ }^{44}$. Further, ROS produced in chloroplasts of water-stressed plants could down-regulate the expression of genes involved in $\mathrm{Chl}$ biosynthesis and photosynthesis via retrograde signaling ${ }^{45,46}$. In water-stressed rice seedlings, there was not only a downregulation of Chl biosynthesis, but also a reduction in pigment-protein complexes; this, obviously, led to lower Chl $a$ fluorescence (Fig. 2). Moreover, biosynthesis of PSII reaction center protein D1 and its repair were also inhibited by $\mathrm{H}_{2} \mathrm{O}_{2}$, and other photosynthetic inhibitors and uncouplers ${ }^{47,48}$. In water-stressed developing rice seedlings components of light-harvesting complexes of both PSII and PSI i.e., Lhcb1, Lhcb2, Lhcal and Lhca4 decreased (Fig. 4). Lack of Chl $b$ in ch1 mutant of Arabidopsis resulted in the absence of accumulation of LHCs, even though they had normal mRNA expression for the $\mathrm{LHCs}^{49}$. Conversely, an increase of Chl $b$ and total Chl content in tobacco upregulated gene expression and protein abundance of different pigment-protein complexes ${ }^{50}$.

In contrast to our present observation in developing rice seedlings, water-stress imposed on four-week-old well developed green wheat plants had no effect on the leaf chlorophyll content, and on the abundance of ATP synthase, PSII, PSI, and light-harvesting complexes ${ }^{51}$. However, in these plants, thylakoid membranes and other proteins were oxidized, due to the generation of ROS as a consequence of excess light absorption by the $\mathrm{LHCs}^{51}$. Decreased LHCII is an essential protection mechanism that allows plants to survive under unfavourable conditions ${ }^{52}$. Our results demonstrate that germinating seedlings protect themselves from water-stress-induced oxidative stress and photo-damage by downsizing their light-harvesting antenna and photosynthetic reaction centers (Figs 4 and 6).

The decreased Fo and Fm (Fig. 1A) in water-stressed rice seedlings is most likely due to a reduced Chl content $^{33}$, and/or stress-induced alteration in xanthophyll-cycle dependent non-radiative energy dissipation ${ }^{53}$. Alternatively, low fluorescence may be related to a state 2 induced during the water-stress treatment. A significant 


\begin{tabular}{|c|c|c|c|c|c|c|c|}
\hline Spot No & Protein & $\begin{array}{l}\text { Mowse } \\
\text { Score }\end{array}$ & $\operatorname{Mr}(\mathbf{k D}) / \mathbf{p I}$ & Access key & $\begin{array}{l}\text { Sequence } \\
\text { Coverage/ } \\
\text { peptides } \\
\text { matched }\end{array}$ & Protein orthologue & $\begin{array}{l}\text { Up/ } \\
\text { down } \\
\text { regul } \\
\text {-ated }\end{array}$ \\
\hline \multicolumn{8}{|c|}{ 1. Carbon fixation: } \\
\hline SSC3-2 & $\begin{array}{l}\text { Ribulose bisphosphate carboxylase } \\
\text { large chain precursor, putative } \\
\text { [Oryza sativa (japonica } \\
\text { cultivar-)] }\end{array}$ & 70.5 & $56.5 / 9.7$ & gi $\mid 108862318$ & $19.3 \% / 10$ & & Down \\
\hline SSC3-8 & Fructose-bisphosphate aldolase & 113 & $41.8 / 6.0$ & gi|108864048 & $34.4 \% / 13$ & & Down \\
\hline SSC3-12 & $\begin{array}{l}\text { Fructose-bisphosphate aldolase } \\
\text { class-I [Oryza sativa Japonica } \\
\text { Group] }\end{array}$ & 77.9 & $39.6 / 7.6$ & gi|62732954 & $23.7 \% / 8$ & & Down \\
\hline SSC3-20 & $\begin{array}{l}\text { hypothetical protein OsJ_30136 } \\
\text { [Oryza sativa Japonica Group] }\end{array}$ & 137 & $26.3 / 9.7$ & gi $\mid 125606445$ & $60.0 \% / 15$ & Triose phosphate isomerase, chloroplastic & Down \\
\hline SSC3-23 & $\begin{array}{l}\text { hypothetical protein OsI_20474 } \\
\text { [Oryza sativa Indica Group] }\end{array}$ & 109 & $30.5 / 7.7$ & gi|125552851 & $43.7 \% / 10$ & Phosphoglycerate kinase, chloroplastic & Down \\
\hline SSC3-11 & $\begin{array}{l}\text { Os01g0501800 [Oryza sativa } \\
\text { (japonica cultivar-group)] }\end{array}$ & 143 & $35.1 / 6.0$ & gi $\mid 115436780$ & $53.8 \% / 15$ & OEC 33 & Down \\
\hline СВС $3-49$ & $\begin{array}{l}\text { PSII Oxygen evolving complex } \\
\text { protein } 2 \text { precursor, rice }\end{array}$ & 332 & $26.932 / 8.66$ & T02B73 & $44 \% / 8$ & & Down \\
\hline \multicolumn{8}{|c|}{ 2. Unknown/Uncharacterized proteins: } \\
\hline SSC3-1 & $\begin{array}{l}\text { Os04g0620200 [Oryza sativa } \\
\text { (japonica cultivar-group)] }\end{array}$ & 45.8 & $31.6 / 9.1$ & gi|115460610 & $24.3 \% / 5$ & $\begin{array}{l}\text { Remorin C-terminal domain protein }+ \\
\text { DNA binding }\end{array}$ & Down \\
\hline SSC3-6 & $\begin{array}{l}\text { hypothetical protein LOC_ } \\
\text { Os11g39500 [Oryza sativa } \\
\text { (japonica cultivar-group)] }\end{array}$ & 33.1 & $13.7 / 9.8$ & gi|77551932 & $18.6 \% / 3$ & Hypothetical protein & Down \\
\hline SSC3-7 & $\begin{array}{l}\text { hypothetical protein OsI_32755 } \\
\text { [Oryza sativa Indica Group] }\end{array}$ & 34.9 & $11.5 / 11.1$ & gi $\mid 218184148$ & $49.0 \% / 3$ & IGR family prot (unknown function) & Down \\
\hline SSC3-18 & $\begin{array}{l}\text { Os01g0652000 [Oryza sativa } \\
\text { (japonica cultivar-group)] }\end{array}$ & 56.4 & $11.3 / 10.7$ & gi|115438911 & $60.8 \% / 5$ & Uncharacterized & Down \\
\hline SSC3-19 & $\begin{array}{l}\text { unknown protein [Oryza sativa } \\
\text { Japonica Group] }\end{array}$ & 44.3 & $12.7 / 10.4$ & gi|47900462 & $28.6 \% / 3$ & Unknown protein & Down \\
\hline СВС-39 & $\begin{array}{l}\text { hypothetical protein [Oryza sativa } \\
\text { Japonica Group] }\end{array}$ & 28.5 & $12.8 / 6.7$ & gi|53791471 & $51.7 \% / 2$ & No match & Down \\
\hline СВС $3-40$ & $\begin{array}{l}\text { hypothetical protein [Oryza sativa } \\
\text { Japonica Group] }\end{array}$ & 59 & $9.9 / 7.8$ & gi|57899958 & $46.4 \%$ & No match & Down \\
\hline CBW3-5 & $\begin{array}{l}\text { hypothetical protein [Oryza } \\
\text { sativa] }\end{array}$ & 45.2 & $15.2 / 11.5$ & gi|10440615 & $59.4 \% / 6$ & No match & Up \\
\hline CBW3-26 & $\begin{array}{l}\text { hypothetical protein [Oryza sativa } \\
\text { Japonica Group] }\end{array}$ & 38.2 & $16.01 / 11.6$ & gi|51534990 & $30.8 \% / 4$ & No match & Up \\
\hline CBW3-27 & $\begin{array}{l}\text { hypothetical protein OsI_26020 } \\
\text { [Oryza sativa Indica Group] }\end{array}$ & 43.1 & $260.7 / 10.8$ & gi|218199617 & $22.8 \% / 8$ & No match & Up \\
\hline CBW3-29 & $\begin{array}{l}\text { Os12g0623600 [Oryza sativa } \\
\text { (japonica cultivar-group)] }\end{array}$ & 34.0 & $32.36 / 7.8$ & gi $\mid 115489646$ & $18.8 \% / 3$ & $\begin{array}{l}\text { Unknown function RmlC_Cupin } \\
\text { domain, DUF1637 family }\end{array}$ & Up \\
\hline CBW3-31 & $\begin{array}{l}\text { hypothetical protein OsI_02030 } \\
\text { [Oryza sativa Indica Group] }\end{array}$ & 46.4 & $12.58 / 9.9$ & gi|125526034 & $37.9 \% / 4$ & No match & Up \\
\hline CBW3-32 & $\begin{array}{l}\text { hypothetical protein [Oryza sativa } \\
\text { Japonica Group] }\end{array}$ & $17.54 / 31.4$ & 12.4 & gi|50251877 & $28.2 \% / 32$ & No match & Up \\
\hline \multicolumn{8}{|c|}{ 3. Cell Homeostasis: } \\
\hline SSC3-4 & \begin{tabular}{|l|} 
hypothetical protein OsJ_22283 \\
[Oryza sativa Japonica Group]
\end{tabular} & 51.9 & $18.6 / 10.1$ & gi|222636049 & $20.9 \% / 4$ & Thioredoxin O; Mitochondrial, OsTrxO1 & Down \\
\hline SSC3-9 & $\begin{array}{l}\text { Os01g0978100 [Oryza sativa } \\
\text { (japonica cultivar-)] }\end{array}$ & 138 & $42.1 / 6.3$ & gi|115442595 & $48.7 \% / 16$ & Putative plastidic cysteine synthase 1 & Down \\
\hline SSC3-13 & $\begin{array}{l}\text { hypothetical protein LOC_- } \\
\text { Os03g32290 [Oryza sativa } \\
\text { (japonica cultivar-group)]; } \\
\text { predicted mitochondrial with } \\
\text { TargetP }\end{array}$ & 42.4 & $11.7 / 5.4$ & gi $\mid 108709024$ & $33.0 \% / 3$ & $\begin{array}{l}\text { Hypothetical protein; low similarity } \\
\text { ( } 51 \% \text { positives) to Glycerol 3-phosphate } \\
\text { dehydrogense }\end{array}$ & Down \\
\hline SSC3-14 & $\begin{array}{l}\text { aminotransferase-like [Oryza } \\
\text { sativa Japonica Group] }\end{array}$ & 54.9 & $20.0 / 4.8$ & gi|50725174 & $37.3 \% / 4$ & & Down \\
\hline SSC3-16 & $\begin{array}{l}\text { hypothetical protein OsJ_04099 } \\
\text { [Oryza sativa Japonica Group] }\end{array}$ & 51.9 & $80.6 / 10.1$ & gi $\mid 222619550$ & $14.6 \% / 6$ & $\begin{array}{l}\text { Chloroplastic, anion transporter 3; have } \\
\text { LRR and receptor kinase like domain; } \\
\text { Alternate phosphate transporter } 4 \\
\end{array}$ & Down \\
\hline СВС3-43 & $\begin{array}{l}\text { Putative malate } \\
\text { dehydrogenaseOryza sativa } \\
\text { (japonica cultivar -group) }\end{array}$ & 306 & $35.414 / 8.22$ & Q6F361_ORYSA & $30 \% / 12$ & & Down \\
\hline СВС3-44 & $\begin{array}{l}\text { Putative malate dehydrogenase } \\
\text { Oryza sativa (japonica cultivar } \\
\text {-group) }\end{array}$ & 215 & $35.439 / 8.74$ & Q94JA2_ORYSA & $22 \% / 7$ & & Down \\
\hline
\end{tabular}




\begin{tabular}{|c|c|c|c|c|c|c|c|}
\hline Spot No & Protein & $\begin{array}{l}\text { Mowse } \\
\text { Score }\end{array}$ & $\operatorname{Mr}(\mathbf{k D}) / \mathbf{p I}$ & Access key & $\begin{array}{l}\text { Sequence } \\
\text { Coverage/ } \\
\text { peptides } \\
\text { matched }\end{array}$ & Protein orthologue & $\begin{array}{l}\text { Up/ } \\
\text { down } \\
\text { regul } \\
\text {-ated }\end{array}$ \\
\hline СВC3-45 & $\begin{array}{l}\text { Putative malate dehydrogenase } \\
\text { Oryza sativa (japonica cultivar } \\
\text {-group) }\end{array}$ & 103 & $35.414 / 8.22$ & Q6F361_ORYSA & $12 \% / 4$ & & Down \\
\hline СBC3-46 & $\begin{array}{l}\text { Malate dehydrogenase } \\
\text { cytoplasmic, Oryza sativa } \\
\text { (japonica cultivar) }\end{array}$ & 221 & $35.415 / 5.75$ & MDHC_ORYSA & $34 \% / 17$ & & Down \\
\hline СВС3-47 & $\begin{array}{l}\text { Putative malate dehydrogenase } \\
\text { mitochondrial Oryza sativa } \\
\text { (japonica cultivar -group) }\end{array}$ & 124 & $35.439 / 8.74$ & Q94JA2_ORYSA & $12 \% / 5$ & & Down \\
\hline CBW3 -24 & $\begin{array}{l}\text { Os04g0174100 [Oryza sativa } \\
\text { (japonica cultivar-group)] }\end{array}$ & 36.9 & $27.7 / 9.0$ & gi|115457106 & $21.7 \% / 4$ & $\begin{array}{l}\text { (CYP family, fragment) or tyrosine } \\
\text { N-monooxygenase }\end{array}$ & Up \\
\hline \multicolumn{8}{|c|}{ 4. Retrotransposons: } \\
\hline SS W3-7 & $\begin{array}{l}\text { putative gag-pol polyprotein } \\
\text { [Oryza sativa (japonica cultivar- } \\
\text { group)] }\end{array}$ & 53.9 & $133.1 / 6.9$ & gi|31126757 & $9.5 \% / 8$ & & Up \\
\hline SS W3-8 & $\begin{array}{l}\text { OSIGBa0146I21.3 [Oryza sativa } \\
\text { (indica cultivar-group)] }\end{array}$ & 54 & $79.35 / 9.8$ & gi $\mid 116309588$ & $9.1 \% / 7$ & $\begin{array}{l}\text { retrotransposon protein, putative, Tyl- } \\
\text { copia subcla }\end{array}$ & Up \\
\hline SS W3-11 & \begin{tabular}{|l} 
Hypothetical protein \\
P0701E03.31.- Oryza sativa \\
(japonica cultivar-group).
\end{tabular} & 18.3 & $6.77 / 4.7$ & Q69YD6_ORYSA & $10.6 \% / 1$ & plant disease resistance polyprotein-like & up \\
\hline \multicolumn{8}{|c|}{ 5. Transcription factors and DNA/RNA binding proteins: } \\
\hline СBC3-35 & $\begin{array}{l}\text { Putative glycine rich protein } 2 \\
\text { Oryza sativa-japonica; have four } \\
\text { CCHC Zn fingers }\end{array}$ & 49 & $22.709 / 6.64$ & Q6YUR8_ORYSA; BAD07599 & $5 \% / 1$ & $\begin{array}{l}\text { Contain S1-like CSD; cold shock domain } \\
\text { protein } 1\end{array}$ & down \\
\hline CBC3-41 & $\begin{array}{l}\text { Os08g0518200 [Oryza sativa } \\
\text { (japonica cultivar-group)] }\end{array}$ & 66.7 & $10.2 / 72.15$ & gi $\mid 115477308$ & $25.3 \% / 12$ & $\begin{array}{l}\text { Mito transcription termination factor } \\
\text { family -related protein }\end{array}$ & down \\
\hline SS W3-14 & $\begin{array}{l}\text { Zinc finger CCCH domain- } \\
\text { containing protein } 31 \\
\text { OS=O.sativa sub. japonica } \\
\mathrm{GN}=\text { Os04g0665700 } \mathrm{PE}=2 \\
\mathrm{SV}=1\end{array}$ & 51.3 & $32.338 / 10.4$ & C3H31_ORYSJ & $29.4 \% / 5$ & & up \\
\hline CBW3-4 & $\begin{array}{l}\text { hypothetical protein OsI_09486 } \\
\text { [O. sativa Indica]; C2H2 Zn-finger }\end{array}$ & 45.7 & $20.5 / 4.9$ & gi $\mid 125541662$ & $13.8 \% / 5$ & $\begin{array}{l}\text { Low Similarity (44\%) to Setaria Zn-finger } \\
\text { prot 7-like }\end{array}$ & up \\
\hline CBW3-25 & $\begin{array}{l}\text { hypothetical protein [Oryza sativa } \\
\text { Japonica Group] }\end{array}$ & 32.6 & $11.8 / 12.6$ & gi|53793156 & $46.7 \% / 4$ & RNA binding glycine-rich protein like & up \\
\hline \multicolumn{8}{|c|}{ 6. Signaling: } \\
\hline SSC3-22 & $\begin{array}{l}\text { Os06g0146100 [Oryza sativa } \\
\text { (japonica cultivar-group)] }\end{array}$ & 47.3 & $118.9 / 9.2$ & gi $\mid 115466384$ & $9.5 \% / 9$ & NBS-LRR disease resistant protein & down \\
\hline SS W3-12 & $\begin{array}{l}\text { Hypothetical protein } \\
\text { OSJNBb0005A04.22.- Oryza } \\
\text { sativa (japonica cultivar). }\end{array}$ & 59.8 & $51.87 / 11.2$ & Q6EQ30_ORYSA & $25.9 \% / 6$ & calcineurin-like phosphoesterase-like & up \\
\hline SS W3-13 & $\begin{array}{l}\text { hypothetical protein OsI_14142 } \\
\text { [Oryza sativa Indica Group] }\end{array}$ & 65.5 & $49.62 / 9.5$ & gi|218194019 & $30.0 \% / 12$ & Putative receptor kinase (tyrosine) & up \\
\hline SS W3-15 & $\begin{array}{l}\text { Os09g0483100 [Oryza sativa } \\
\text { (japonica cultivar-group)] }\end{array}$ & 59.3 & $15.076 / 4.2$ & gi|115479825 & $65.2 \% / 5$ & $\mathrm{Ca}^{+2}$ binding EF-hand 5 motif prot & up \\
\hline CBW3-1 & $\begin{array}{l}\text { hypothetical protein - } \\
\text { OSJNBa0016I09.17.- Oryza sativa } \\
\text { (japonica cultivar) }\end{array}$ & 49.5 & $30.4 / 10.7$ & Q5QNA8_ORYSA & $26.4 \% / 5$ & Similar to receptor like kinase & up \\
\hline CBW3-10 & $\begin{array}{l}\text { Phosphatidylinositol-4-phosphate } \\
\text { 5-kinase 4, putative, expressed } \\
\text { [Oryza sativa (japonica cultivar)] }\end{array}$ & 53.5 & $84.93 / 9.7$ & gi $\mid 108708236$ & $13.5 \% / 8$ & & up \\
\hline \multicolumn{8}{|c|}{ 7. Energy balance: } \\
\hline SSC3-15 & $\begin{array}{l}\text { Os02g0750100 [Oryza sativa } \\
\text { (japonica cultivar-group)] }\end{array}$ & 57.2 & $26.2 / 4.8$ & gi|115448701 & $23.5 \% / 6$ & $\mathrm{H}+$ transporting ATP synthase, $\delta$ chain & down \\
\hline SSC3-21 & $\begin{array}{l}\text { putative inorganic } \\
\text { pyrophosphatase [Oryza sativa } \\
\text { Japonica Group] }\end{array}$ & 155 & $31.8 / 5.7$ & gi|46805452 & $42.3 \% / 14$ & & down \\
\hline СВС3-34 & $\begin{array}{l}\text { AP003518 NID: Oryza sativa- } \\
\text { japonica cultivar }\end{array}$ & 58 & $41.315 / 6.68$ & BAD37348 & $6 \% / 3$ & $\begin{array}{l}\text { Formate dehydrogenase, mitochondrial } \\
\text { precursor }\end{array}$ & down \\
\hline \multicolumn{8}{|c|}{ 8. Protein folding/de-folding and degradation: } \\
\hline SSC3-3 & $\begin{array}{l}\text { putative Lon protease [Oryza } \\
\text { sativa Japonica Group] }\end{array}$ & 33.1 & $96.9 / 7.0$ & gi|50725794 & $6.9 \% / 4$ & & down \\
\hline СВС3-42 & $\begin{array}{l}\text { Putative peptidylprolyl isomerase } \\
\text { Oryza sativa (japonica cultivar } \\
\text {-group) }\end{array}$ & 140 & $26.574 / 9.37$ & Q75M32_ORYSA & $24 \% / 5$ & & down \\
\hline \multicolumn{8}{|c|}{ 9. Antioxidant proteins: } \\
\hline CBW3-28 & $\begin{array}{l}\text { Os03g0285700 [Oryza sativa } \\
\text { (japonica cultivar-group)] }\end{array}$ & 66.4 & $27.02 / 5.3$ & gi $\mid 115452337$ & $54.8 \% / 10$ & APxl & up \\
\hline \multicolumn{8}{|c|}{ Continued } \\
\hline
\end{tabular}




\begin{tabular}{|c|c|c|c|c|c|c|c|}
\hline Spot No & Protein & $\begin{array}{l}\text { Mowse } \\
\text { Score }\end{array}$ & $\operatorname{Mr}(\mathbf{k D}) / \mathbf{p I}$ & Access key & $\begin{array}{l}\text { Sequence } \\
\text { Coverage/ } \\
\text { peptides } \\
\text { matched }\end{array}$ & Protein orthologue & $\begin{array}{l}\text { Up/ } \\
\text { down } \\
\text { regul } \\
\text {-ated }\end{array}$ \\
\hline CBW3-30 & $\begin{array}{l}\text { Os05g0116100 [Oryza sativa } \\
\text { (japonica cultivar-group)] }\end{array}$ & 141 & $23.44 / 5.8$ & gi|115461741 & $41.8 \% / 9$ & GST_C family, DHAR & up \\
\hline \multicolumn{8}{|c|}{ 10. Cell shape/cytoskeleton protein: } \\
\hline SSW3-6 & $\begin{array}{l}\text { Os04g0538800 [Oryza sativa } \\
\text { (japonica cultivar-group)] }\end{array}$ & 71.5 & $106.4 / 6.6$ & gi|115459666 & $12.3 \% / 8$ & Similar to Kinesin heavy chain (fragment) & up \\
\hline SSC3-5 & $\begin{array}{l}\text { hypothetical protein OsI_28608 } \\
\text { [Oryza sativa Indica Group] }\end{array}$ & 39.9 & $57.6 / 0.0$ & gi|125560931 & $0.0 \% / 3$ & $\begin{array}{l}\text { Similar to Transducin/WD-40 repeat } \\
\text { protein-like }\end{array}$ & down \\
\hline CBW3-3 & $\begin{array}{l}\text { Hypothetical protein.-Oryza } \\
\text { sativa (japonica cultivar-group). } \\
\text { Os12g0465000 }\end{array}$ & 28 & $14.1 / 10.2$ & Q2QRD6_ORYSA & $22.0 \% / 2$ & $\begin{array}{l}\text { Similar (68\% positives) to Saccharum } \\
\text { hybrid R570, A0A059Q350 } \\
\text { Acetylglucosaminyl transferase family } \\
\text { protein }\end{array}$ & up \\
\hline \multicolumn{8}{|c|}{ 11. mRNA processing: } \\
\hline СВС3-33 & $\begin{array}{l}\text { Hypothetical Protein OJ1611_- } \\
\text { C08.15.-Oryza sativa (japonica } \\
\text { cultivar -group) }\end{array}$ & 39 & $132.188 / 5.57$ & Q6ZHF3_ORYSA & $1 \% / 1$ & $\begin{array}{l}\text { UPF0614 C14orf102-like protein; have } \\
\text { HAT and NRDE-2 domains }\end{array}$ & down \\
\hline \multicolumn{8}{|c|}{ 12. Proteins with specific functions: } \\
\hline SSW3-9 & $\begin{array}{l}\text { IAA-amino acid hydrolase } \\
\text { ILR1-like } 3 \text { O.sativa sub japon ica } \\
\text { GN = ILL3 PE }=2 \mathrm{SV}=1\end{array}$ & 47.8 & $44.07 / 5.4$ & ILL3_ORYSJ & $23.0 \% / 5$ & & up \\
\hline SSW3-10 & $\begin{array}{l}\text { IAA-amino acid hydrolase ILR1- } \\
\text { like } 3 \text { OS = Oryza sativa subsp. } \\
\text { japonica }\end{array}$ & 47.4 & $44.07 / 5.4$ & ILL3_ORYSJ & $17.0 \% / 6$ & & up \\
\hline CBW3-2 & $\begin{array}{l}\text { Salt stress-induced protein (Salt } \\
\text { protein) (Protein mannose- } \\
\text { binding lectin).- Oryza sativa }\end{array}$ & 72 & $15.03 / 4.9$ & SALT_ORYSA & $45.8 \% / 5$ & & up \\
\hline
\end{tabular}

Table 1. Differentially expressed proteins in water-stressed rice seedlings categorized into different subgroups

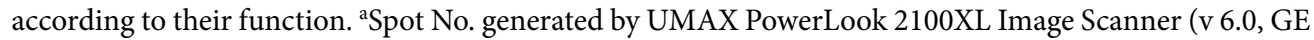
Healthcare); Numbered spots correspond to the identified proteins,.refer the spots shown on the representative image in Fig. 7. ${ }^{\mathrm{b}}$ Accession number from NCBI database. SC, sequence coverage; Mr, theoretical Molecular weight; pI, theoretical Isoelectric point; Fold change refers to increased (Up) or decreased levels (down) of protein content from control to water-stressed seedlings. Fold change \pm 2 was used as threshold for protein identification. Orthologues were obtained by using Uniprot protein sequence and BLAST.

decrease in Fv/Fm, which is a proxy of PSII photochemistry efficiency ${ }^{37}$, in water-stressed developing seedlings (Fig. 1A), might have resulted from the down-regulation of synthesis and assembly of PSII reaction centers. This would have reduced not only the concentration of PSII reaction centers, but also of the oxygen evolving complex proteins, such as OEC33 (PsbO), OEC23 (PsbP) and OEC 16 (PsbQ) (Fig. 4). The observed changes in Chl $a$ fluorescence spectra (Fig. 2) are in agreement with this observation. Furthermore, the "operating" quantum yield of PSII ( $\phi$ PSII) during actinic illumination also sharply declined in water-stressed developing seedlings (Fig. 1B), OEC33 is important for stabilization of $\mathrm{Mn}$ and $\mathrm{Cl}$ co-factors in water oxidizing complexes ${ }^{54}$; its reduction via RNAi results in a decrease in quantum yield of photosynthesis ${ }^{55}$. Beside providing appropriate amounts of calcium and chloride ions for water splitting reactions, OEC23 and OEC16 play an additional role in the assembly of PSII supercomplexes, and their decreased abundance was clearly correlated with reduced PSII-dependent $\mathrm{O}_{2}$ evolution $^{54}$; therefore, down-regulation of OEC proteins also explains the impaired PSII-dependent water oxidation and oxygen evolution that we found in thylakoid membranes isolated from water-stressed developing seedlings (Fig. 3).

Higher NPQ in water-stressed seedlings compared to the controls at all measured PAR values, especially at low actinic light intensities (Fig. 1C) suggest an adaptive response of developing seedlings for increased dissipation of absorbed energy as heat to protect their thylakoid membranes from photodamage ${ }^{29}$. Down-regulation of $\delta$-subunit of ATP synthase was observed in our proteome profile of water-stressed seedlings (Table 1). Impaired ATP synthase would have resulted in reduced transport of protons across the thylakoid membrane; the lowered dissipation of $\Delta \mathrm{pH}$ and increased acidification of the lumen ${ }^{56}$ could lead to higher NPQ in (water) stressed seedlings even at low light intensities.

In water-stressed samples, reduced amount of Chl, LHCs and reaction center proteins result in reduced light absorption, and decreased amount of oxygen evolving complex proteins result in reduced utilization of the absorbed energy. Consequently, reduction of PSII activity was almost similar (nearly 50\%) under limiting as well as under saturating light intensities. In the same vein, the downsizing of the light-harvesting Chl-binding proteins of PSI i.e., LHCI (Lhcal and Lhca4) and PSI core complex protein subunits III (PsaF), V (PsaK) and VI (PsaH) in water-stressed seedlings, resulted in diminished light absorption as well as light utilization by PSI, as was evident from the reduction of PSI reaction by $30 \%$ at limiting and higher light intensities (Fig. 3E). Relatively lower reduction of PSI activity than that of PSII (Fig. 3) suggests that development of PSI of developing rice seedlings is more tolerant to water-stress. The Eadie plot $^{31,40}$ for control and treated seedlings revealed a marked drop in the quantum efficiency of PSI and PSII reactions and a substantial reduction of Vmax in stressed developing 
seedlings (Fig. 3); these suggest a coordinated developmental down-regulation of light-harvesting and reaction center proteins of PSI as well as PSII in response to osmotic stress ${ }^{31,40}$.

Room temperature fluorescence emission spectrum of thylakoid membranes had a peak at $684 \mathrm{~nm}$ due to PSII, when they were excited at $440 \mathrm{~nm}$ (Fig. 2A). Water-stressed samples had a reduced fluorescence emission, probably due to a block in electron donation from water side of PSII; decreased abundance of oxygen evolving complex proteins $(33 \mathrm{kDa}, 23 \mathrm{kDa}$ and $18 \mathrm{kDa})$ supports this hypothesis. Gross perturbation of structural organization of thylakoid membranes usually induces differences in fluorescence spectra at low temperature $(77 \mathrm{~K})$; these spectra usually have emission peaks at $685 \mathrm{~nm}\left(\mathrm{~F}_{685}\right)$, at $695 \mathrm{~nm}\left(\mathrm{~F}_{695}\right)$, which mostly originates from PSII $\mathrm{CP} 43$ and CP47 respectively ${ }^{38}$, and a $\mathrm{F}_{735-740}$ peak that originates mostly from PSI ${ }^{57}$. If a part of LHCI antenna is removed from PSI by detergent treatment, the inner antenna of the PSI reaction center fluoresces at $722 \mathrm{~nm}^{58}$, while isolated LHCI complexes fluoresce around $735-740 \mathrm{~nm}$; this is consistent with the assignment by Briantais et al. ${ }^{59}$ : the inner PSI antenna for $\mathrm{F}_{722}$ and for LHC I for $\mathrm{F}_{735-740}{ }^{59}$. A shift to $\mathrm{F}_{738}$ from $\mathrm{F}_{740}$ in our water-stressed samples are due to a partial loss of components of LHCI.

In the absence of $\mathrm{Mg}^{2+}$, the $\mathrm{F}_{686} / \mathrm{F}_{740}$ ratio in thylakoid membranes isolated from control seedlings was $\sim 1.54$ (Fig. 2B). In experiments by others, LHCII has been shown to migrate closer to PSII $^{60}$ in presence of $\mathrm{Mg}^{+2}$, leading to stacking of thylakoids into granum ${ }^{61}$ (see a review on role of ions by Kaňa and Govindjee) ${ }^{62}$. This results in efficient energy transfer from LHCII to the reaction center of PSII, and consequently, an increase in PSII fluorescence at $686 \mathrm{~nm}$ and, thus, higher $\mathrm{F}_{686} / \mathrm{F}_{740}$ [see Results] ratio (an increase of $\mathrm{F}_{686} / \mathrm{F}_{740}$ ratio to 1.73 in the control samples with $\mathrm{Mg}^{2+}$, compared to 1.54 without $\mathrm{Mg}^{2+}$ (Fig. 2B)). In water-stressed seedlings, $\mathrm{Mg}^{+2}$-induced increase in $\mathrm{F}_{686} / \mathrm{F}_{740}$ was almost similar to control. Although a reduced grana stacking was observed in electron micrographs of the plastids of water-stressed seedlings, they retained the ability of $\mathrm{Mg}^{2+}$-induced migration of LHCPII to PSII core complex.

As revealed from our proteomics studies, water-stressed rice seedlings downsized their carbon reduction cycle enzymes i.e., Rubisco LSU, fructose bisphosphate aldolase (FBA), triosephosphate isomerase (TPI) and phosphoglycerate kinase (3PGK) (Table 1). In contrast, in water-stressed well-developed plants, Rubisco content was often not affected, although its initial and total activity is known to decrease due to blocking of catalytic sites by 2 -carboxyarabinitol-1-phosphate and other sugar phosphates ${ }^{63}$. Sugar phosphates can be removed from Rubisco by ATP-dependent enzyme Rubisco activase ${ }^{17}$, leading to its reactivation, hence underlining the role of Rubisco activase and ATP production in regulating carbon assimilation under drought. Drought-induced stomatal closure, and consequent decreased carboxylation, also result in down-regulation of protein abundance of Calvin-Benson cycle enzymes ${ }^{13-16}$.

Down-regulation of peptidyl prolyl isomerase (PPIase), in our water-stressed rice seedlings, suggest that there was a decrease in the ability to repair photosynthetic proteins, which, in turn, results in reduced PSI and PSII activities.

In mature plants, only minimal amounts of $\mathrm{Chl}$ and proteins are synthesized, mostly to replace those photodestroyed in PSI and PSII and LHCs, due to light. Therefore, it appears that mature plants do not downsize the components of the photosynthetic apparatus in response to drought. Several studies have demonstrated that abiotic stresses, including water-stress, cause ROS production due to an over-reduction of photosynthetic electron transport chain ${ }^{25,29,64,65}$. Abiotic stresses also impair reaction centers of well-developed seedlings or mature plants, leading to reduced transfer of absorbed light energy from light harvesting complexes to photodamaged reaction centers and consequently generation of higher amounts of singlet oxygen via photosensitization reactions of $\mathrm{Chl}^{27,28,31}$. Well developed rice plants treated for $48 \mathrm{~h}$ with 30\% PEG 6000, a concentration similar to that used in our current experimental protocol, accumulated 2.5-4 fold higher $\mathrm{H}_{2} \mathrm{O}_{2}$, which impaired Rubisco activity and promoted stomatal closure ${ }^{25}$. However, we showed that germinating seedlings protect themselves by downsizing their light-harvesting antenna and photosynthetic reaction centers to reduce ROS production (Figs 4 and 6). In addition, we found that antioxidative enzymes i.e., ascorbate peroxidase 1 (APx1) and dehydroascorbate reductase (DHAR), were up-regulated in developing stressed seedlings (Table 1) to neutralize comparatively smaller amount of ROS generated. Therefore, we did not observe any increase of $\mathrm{H}_{2} \mathrm{O}_{2}$ in developing seedlings subjected to water-stress for $24 \mathrm{~h}$, and there was only a small increase $(23 \%)$ after $72 \mathrm{~h}$. Consequently, membrane lipid peroxidation, monitored as MDA production did not increase after $24 \mathrm{~h}$ of stress treatment, but it increased by $50 \%$ only after $72 \mathrm{~h}$.

In conclusion, we can clearly state that unlike mature plants, seedlings exposed to water-stress during early photomorphogenesis, protect themselves from photo-oxidative stress by downsizing their photosynthetic apparatus. Therefore, we recommend that attempts should be made to down-regulate the light absorption during stress condition by reducing $\mathrm{Chl}$ biosynthesis. This can be achieved by either using molecular marker assisted plant breeding methods or by using transgenic RNAi approaches, silencing the expression of gene encoding for glutamyl-tRNA reductase or other early enzymes responsible for the synthesis of 5-aminolevulinic acid, a precursor of Chl biosynthesis. The RNAi expression could be modulated by promoters that sense increased ROS (e.g., $\mathrm{H}_{2} \mathrm{O}_{2}$ ) produced during stress conditions.

\section{Materials and Methods}

Plants growth conditions and stress treatment. Seeds of drought-sensitive rice (Oryza sativa) cultivar Pusa Basmati-1 (PB-1) were obtained from the Indian Agricultural Research Institute, New Delhi, India. Five-day old etiolated seedlings, grown at $25^{\circ} \mathrm{C}$, were treated with half-strength $\mathrm{MS}^{66}$ solution, or half-strength MS solution $+40 \mathrm{mM}$ PEG $(-0.73 \mathrm{MPa})$ or $50 \mathrm{mM}$ PEG $6000(-1.06 \mathrm{MPa} \text {; Merck, Kenilworth, NJ })^{35}$, 16 h prior to their transfer to continuous cool-white fluorescent (plus incandescent) light of $100 \mu \mathrm{mol}$ photons $\mathrm{m}^{-2} \mathrm{~s}^{-1}$; low light intensity was used to avoid photodamage of the seedlings during greening. The seedlings were maintained for 3 days at $28^{\circ} \mathrm{C}$ and at $75 \%$ relative humidity in a Conviron plant growth chamber. 
Polarographic measurement of photosynthetic electron transport. Approximately $5 \mathrm{~g}$ of leaves were homogenized in $40 \mathrm{ml}$ of isolation buffer containing $0.4 \mathrm{M}$ sorbitol, $0.05 \mathrm{M}$ Hepes/KOH (pH 7.3), $1 \mathrm{mM}$ $\mathrm{MgCl}_{2}$, and $1 \mathrm{mM} \mathrm{EDTA}$ at $4{ }^{\circ} \mathrm{C}$, under green safe light (28 Chakraborty and Tripathy, 1992). The homogenate was passed through 8 layers of cheese cloth and 1 layer of Mira cloth, and centrifuged at 5,000 rpm for $7 \mathrm{~min}$. The pellet was suspended in a buffer solution containing $0.4 \mathrm{M}$ sorbitol, $0.05 \mathrm{M}$ Tris ( $\mathrm{pH} 7.6), 1 \mathrm{mM} \mathrm{MgCl}_{2}$ and $1 \mathrm{mM}$ EDTA; Chl concentration was estimated according to Porra et al. ${ }^{67}$.

Photosynthetic electron transport was measured at $25 \pm 1{ }^{\circ} \mathrm{C}$ with a Clark-type oxygen electrode (Hansatech, Kings Lynn, UK), by using $1 \mathrm{ml}$ suspension of thylakoid membranes containing $20 \mu \mathrm{g} \mathrm{Chl} \mathrm{ml}{ }^{-1}$; illumination was with white-light from a tungsten source of $1,500 \mu \mathrm{mol}$ photons $\mathrm{m}^{-2} \mathrm{~s}^{-1}$. The whole electron transport chain, from $\mathrm{H}_{2} \mathrm{O}$ to methylviologen (MV) $(1 \mathrm{mM})$, was monitored as $\mathrm{O}_{2}$ uptake ${ }^{68,69}$. PSII activity was monitored as $\mathrm{O}_{2}$ evolution resulting from electron transport from $\mathrm{H}_{2} \mathrm{O}$ to $\mathrm{p}$-phenylenediamine (PD) $(0.5 \mathrm{mM})$. The partial electron transport through PSI was measured as oxygen consumption. Ascorbate $(1 \mathrm{mM}) / \mathrm{DCIP}(0.2 \mathrm{mM})$ couple was used as electron donor to PSI, and MV $(1 \mathrm{mM})$ as electron acceptor ${ }^{68,69}$; the electron flow from PSII was blocked by 3-(3, 4-dichlorophenyl) 1,1-dimethyl urea (DCMU) $(20 \mu \mathrm{M})$, and $1 \mathrm{mM}$ sodiumazide was used as an inhibitor of catalase.

Light saturation curves were measured at several light intensities obtained by using neutral density filters (Balzers, Neugrüt, Lichtenstein).

Transmission electron microscopy. Leaves (in triplicate) were fixed with $2.5 \%$ glutaraldehyde ${ }^{70}$ and $1 \% \mathrm{OsO}_{4}$ for $2-4 \mathrm{~h}$, and then washed, dehydrated with acetone, cleared with epoxy propane/xylene, and infiltrated with resin containing araldite and toluene (up to $75 \%$ araldite). After embedding, araldite was polymerized at $50^{\circ} \mathrm{C}$, and then at $60^{\circ} \mathrm{C}$. Ultra-thin sections were cut, stained in saturated uranyl acetate in $50 \%$ ethanol, washed in 50\% ethanol and water, and viewed in a Transmission Electron Microscope (TEM) (Phillips-CM-10, Eindhoven, Netherlands).

Chlorophyll a fluorescence measurements. Chl $a$ fluorescence signal is a highly sensitive signature of diverse aspects of photosynthesis, and thus, it is widely used in photosynthesis research ${ }^{38,71}$ (see chapters in Papageorgiou and Govindjee) $)^{72}$.

Fluorescence emission spectra of isolated thylakoids. Room temperature (RT; $298 \mathrm{~K})$ and low temperature (77 K) fluorescence emission spectra of isolated thylakoids were recorded with a SLM-AMINCO-8000 spectrofluorometer; for $77 \mathrm{~K}$-spectra, the excitation and emission slit widths were $4 \mathrm{~nm}$, while for RT-spectra, the excitation and emission slit widths were $8 \mathrm{~nm}$ and $4 \mathrm{~nm}$ respectively. Rhodamine-B was used in the reference channel as quantum counter. A tetraphenylbutadiene block was used to adjust the voltage in sample, as well as in reference channels to 20000 counts s ${ }^{-1}$ at excitation and emission wavelengths of $348 \mathrm{~nm}$ and $422 \mathrm{~nm}$, respectively. RT-spectra were corrected for the instrument response.

Thylakoid isolation. Leaves from control and water-stressed seedlings were grounded in Hepes- NaOH buffer, pH 7.6 (20 mM Hepes, $10 \mathrm{mM} \mathrm{NaCl}, 0.4 \mathrm{M}$ sucrose, $0.5 \% \mathrm{BSA}$ ) and then centrifuged at 5,000 rpm for $7 \mathrm{~min}$; pellet was suspended in $5 \mathrm{mM}$ Hepes- $\mathrm{NaOH}$ buffer ( $\mathrm{pH}$ 7.5) containing 0 or $4 \mathrm{mM} \mathrm{MgCl}_{2}$. Thylakoids equivalent to $3 \mu \mathrm{g} \mathrm{Chl} \mathrm{ml}{ }^{-1}$ were used for RT- and 77K-spectra (25\% glycerol) at excitation wavelength of $440 \mathrm{~nm}$ and emission wavelength range of 620-750 $\mathrm{nm}$ and of 620-780 nm, respectively ${ }^{31}$. Each experiment was performed three times.

Chl a fluorescence induction curves. Chl a fluorescence induction curves at $25^{\circ} \mathrm{C}$ were recorded on attached leaves, with a portable PAM-2100 fluorometer (Walz, Effeltrich, Germany); all measurements were repeated 3 times. The initial (Fo) and maximum (Fm) fluorescence, was measured on seedlings that were dark-adapted for $20 \mathrm{~min}$; the measuring light was red $(650 \mathrm{~nm})$, and of very low intensity $\left(<0.1 \mu \mathrm{mol}\right.$ photons $\left.\mathrm{m}^{-2} \mathrm{~s}^{-1}\right)$; its frequency was $0.6 \mathrm{KHz}$. Then, a $0.8 \mathrm{~s}$ saturation light pulse of approximately $8,000 \mu \mathrm{mol}$ photons $\mathrm{m}^{-2} \mathrm{~s}^{-1}$ was applied to measure the maximum fluorescence, Fm. The Fo and the Fm values were used to calculate the ratio $\mathrm{Fv} / \mathrm{Fm}=(\mathrm{Fm}-\mathrm{Fo}) / \mathrm{Fm}$, where $\mathrm{Fv}$ is the maximum variable fluorescence; this ratio represents the maximum quantum yield of PSII photochemistry. Light response curves were obtained by measuring fluorescence as a function of increasing actinic light intensity ( 4 to $270 \mu \mathrm{mol}$ photons $\mathrm{m}^{-2} \mathrm{~s}^{-1}$; wavelength: $665 \mathrm{~nm}$ ). The quantum yield of PSII $\left(\phi\right.$ PSII) was calculated as $\left(\mathrm{Fm}^{\prime}-\mathrm{Ft}\right) / \mathrm{Fm}^{\prime}$, where $\mathrm{Fm}^{\prime}$ is the maximum fluorescence at steady state in pre-illuminated samples, and $\mathrm{Ft}$ is fluorescence immediately before the application of the saturation pulse $\mathrm{e}^{37}$. Non-photochemical quenching (NPQ) was calculated as $\left(\mathrm{Fm}-\mathrm{Fm}^{\prime}\right) / \mathrm{Fm}^{\prime}$.

Thylakoid isolation and western blotting. $20 \mu \mathrm{g}$ of plastid protein ${ }^{28}$, estimated as described by Bradford $^{73}$, was separated on SDS-PAGE three times for each photosynthetic target protein, transferred to nitrocellulose (NC) membranes and blocked with BSA solution. Subsequently, blots were incubated with polyclonal and heterologous primary antibodies (Supplementary Table S4) and alkaline phosphatase-conjugated antibodies and developed for color. Image J (NIH, USA) was used for quantification.

Estimation of malondialdehyde (MDA). $200 \mathrm{mg}$ fresh tissue was homogenized in $20 \%(\mathrm{w} / \mathrm{v})$ trichloroacetic acid (TCA) alone (-TBA (Thiobarbituric acid)) or $20 \%$ TCA (w/v) plus $0.25 \%$ TBA $(+ \text { TBA })^{41}$. Samples were vortexed, heated at $95^{\circ} \mathrm{C}$ in a water bath for $25 \mathrm{~min}$, cooled, and centrifuged at $12,000 \mathrm{rpm}$ for $10 \mathrm{~min}$. Absorbance was read at 440,532, and $600 \mathrm{~nm}$. MDA equivalent was calculated as follows: $\mathrm{A}=(\mathrm{Abs}$ $\left.532_{+\mathrm{TBA}}\right)-\left(\right.$ Abs $\left.600_{+\mathrm{TBA}}\right)-\left(\right.$ Abs $\left.532_{-\mathrm{TBA}}\right)-\left(\right.$ Abs $\left.\left.600_{-\mathrm{TBA}}\right)\right) ; \mathrm{B}=\left(\right.$ Abs $440_{+\mathrm{TBA}}-$ Abs $\left.600_{+\mathrm{TBA}}\right) 0.057$; and finally as: $(\mathrm{A}-\mathrm{B} / 1,57,000) 10^{6}\left(\mathrm{in} \mathrm{nmol} \mathrm{ml}^{-1}\right)$. 
Determination of hydrogen peroxide. Leaf tissue $(200 \mathrm{mg})$ was homogenized in $2 \mathrm{ml}$ of $0.1 \%(\mathrm{w} / \mathrm{v})$ TCA solution on ice ${ }^{74}$ and centrifuged at $12,000 \mathrm{~g}$ for $15 \mathrm{~min} .0 .4 \mathrm{ml}$ of the supernatant was added to $0.4 \mathrm{ml}$ of 10 $\mathrm{mM}$ potassium phosphate buffer $(\mathrm{pH} 7.0)$ and $0.8 \mathrm{ml}$ of $1 \mathrm{M} \mathrm{KI}$; the absorbance was measured at $390 \mathrm{~nm}$. The leaf $\mathrm{H}_{2} \mathrm{O}_{2}$ content was measured using standard calibration curve of $\mathrm{H}_{2} \mathrm{O}_{2}$ (Thermo Fisher Scientific, MA).

Statistical analysis. All measurements were subjected to analysis of variance (ANOVA) to check for significance level of differences (defined as $\mathrm{p}<0.05$ ). Data is shown as mean \pm standard deviation (SD).

2-Dimensional gel electrophoresis. Isolation of soluble and loosely bound thylakoid proteins. After 72 $\mathrm{h}$ of greening, two grams of tissue was homogenized in $10 \mathrm{ml}$ of ice-cold $\mathrm{Mg} / \mathrm{NP}-40$ extraction buffer containing $0.5 \mathrm{M}$ Tris- $\mathrm{HCl}, \mathrm{pH} 8.3,2 \% \mathrm{v} / \mathrm{v} \mathrm{NP}-40,20 \mathrm{mM} \mathrm{MgCl} 2,2 \% \mathrm{v} / \mathrm{v} \beta$-mercaptoethanol, $1 \mathrm{mM}$ phenylmethylsulfonyl fluoride and $1 \% \mathrm{w} / \mathrm{v}$ polyvinylpolypyrrolidone $\mathrm{e}^{75}$; this was repeated several times until a consistent pattern was obtained. After centrifugation at $12,000 \mathrm{~g}$ for $15 \mathrm{~min}$ at $4{ }^{\circ} \mathrm{C}, 50 \%(\mathrm{w} / \mathrm{v})$ PEG-4000 stock solution was added to the supernatant to a final concentration of $10 \%$ PEG. The solution was incubated in ice and centrifuged at 1,500 $\mathrm{g}$ for $15 \mathrm{~min}$ each. The supernatant was adjusted to $15 \%$ (Silver-stained) or 20\% (CBB-stained) PEG by adding 50\% (w/v) PEG-4000 stock, incubated and centrifuged as described above. For silver- and CBB-stained gels, $150 \mu \mathrm{g}$ and $800 \mu \mathrm{g}$ of protein from resulting supernatant was treated with PERFECT-FOCUS ${ }^{\mathrm{TM}}$ kit from Geno Biosciences (St. Louis, MO); the pellet, thus obtained, was washed and air dried.

Isoelectric focusing and 2-D gel-electrophoresis. Air dried pellet was dissolved in rehydration buffer containing $8 \mathrm{M}$ urea, 3\% CHAPS, $20 \mathrm{mM}$ DTT, $1 \mathrm{mM}$ PMSF, and 2\% ampholyte (GE-Healthcare, Buckinghamshire, UK). Protein extract was loaded on a 17 cm IPG strip of pH 3-10 (4-7 in case of silver-stained gels) (Bio Rad, CA). Rehydration was followed by electrophoresis at $250 \mathrm{~V}$ for $0.5 \mathrm{~h}, 10,000 \mathrm{~V}$ for $3.5 \mathrm{~h}$, and $40,000 \mathrm{VH}$ at $10,000 \mathrm{~V}$.

After equilibration of the strips, proteins were separated on 12.5\% SDS-PAGE. Gels were scanned with UMAX PowerLook-2100XL Image Scanner (GE-Healthcare). Spots were detected, matched, and edited with Image Master-2D Platinum 6.0 software (GE-Healthcare).

Mass spectrometry and database search. Protein spots showing two fold or higher difference (\% vol) were excised, destained, digested and extracted ${ }^{76}$. For one set of spots, matrix-assisted laser desorption ionization (MALDI) with Bruker Autoflex II TOF/TOF mass spectrometer (Bruker Daltonics, Billerica, MI) was used ${ }^{76}$. The peptide mass data were searched against NCBInr (non-redundant) Oryza sativa/green plant database with the Mascot search engine (Matrix Science Ltd., UK). Two missed cleavage sites were allowed, cysteine was carbamidomethylated and methionine was allowed to be partially oxidized.

Other sets of proteins were detected with LC-MS/MS ${ }^{12}$. MS analysis was performed on Applied Biosystems 4000-Q-TRAP-system (Foster City, CA), equipped with Agilent 1200-NanoLC system (Santa Clara, CA). Proteins were excised manually, destained, digested and extracted. LC separation of peptides was performed on ZORBAX 300 SB-C18 silica column, increasing the gradient from 3 to $97 \%$ acetonitrile in $0.1 \%$ formic acid. The first MS detected ions were at scan range of $400-1600 \mathrm{~m} / \mathrm{z}$. Fragmentation spectra were submitted by Sequest algorithm to BioWorks (v3.3.1; Thermo Scientific) for searching a composite database of proteins using mascot (http://www. matrixscience.com/). Search settings applied were: trypsin as cleaving enzyme, maximally two missed cleavages, peptide mass tolerance $15 \mathrm{ppm}$, fragment ion tolerance $0.5 \mathrm{Da}$, and no differential post-translational modifications were allowed per peptide.

UNIPROT and University of Western Australia rice database (http://ricedb.plantenergy.uwa.edu.au/) ${ }^{77}$ were used for gene annotations of identified proteins. Gene ontology (GO) enrichment analysis was performed with ricearray (http://www.ricearray.org/analysis/go_enrichment.php) using default parameters.

Data availability. Most of the data generated or analysed during this study are included in this published article (and its supplementary information files). Any other remaining necessary data is available from the corresponding author upon reasonable request.

\section{References}

1. Pareek, A., Sopory, S. K. \& Bohnert, H. J. Govindjee (eds) Abiotic Stress Adaptation in Plants, Physiological, Molecular and Genomic Foundation (Springer, Dordrecht, 2010).

2. Zhao, M. S. \& Running, S. W. Drought-Induced reduction in global terrestrial net primary production from 2000 through 2009. Science 329, 940-943 (2010).

3. Lawlor, D. W. \& Tezara, W. Causes of decreased photosynthetic rate and metabolic capacity in water-deficient leaf cells: a critical evaluation of mechanisms and integration of processes. Annal. Bot. 103, 561-579 (2009).

4. Pinheiro, C. \& Chaves, M. M. Photosynthesis and drought: can we make metabolic connections from available data? J. Exp. Bot. 62, 869-882 (2011).

5. Chaves, M. M., Flexas, J. \& Pinheiro, C. Photosynthesis under drought and salt stress: Regulation mechanisms from whole plant to cell. Annal. Bot. 103, 551-560 (2009).

6. Evans, J. R., Kaldenhoff, R., Genty, B. \& Terashima, I. Resistances along the $\mathrm{CO}_{2}$ diffusion pathway inside leaves. J. Exp. Bot. 60, 2235-2248 (2009).

7. Tezara, W., Mitchell, V., Driscoll, S. D. \& Lawlor, D. W. Water stress inhibits plant photosynthesis by decreasing coupling factor and ATP. Nature 401, 914-917 (1999).

8. Miyazawa, S. I., Yoshimura, S., Shinzaki, Y., Maeshima, M. \& Miyake, C. Deactivation of aquaporins decreases internal conductance to $\mathrm{CO}_{2}$ diffusion in tobacco leaves grown under long term drought. Funct. Plant Biol. 35, 553-564 (2008).

9. Maroco, J. P., Rodrigues, M. L., Lopes, C. \& Chaves, M. M. Limitations to leaf photosynthesis in field-grown grapevine under drought -metabolic and modelling approaches. Funct. Plant Biol. 29, 451-459 (2002).

10. Salekdeh, G. H., Siopongco, J., Wade, L. J., Ghareyazie, B. \& Bennett, J. Proteomic analysis of rice leaves during drought stress and recovery. Proteomics 2, 1131-1145 (2002).

11. Liu, W. J. et al. Effect of water stress on photosystem 2 in two wheat cultivars. Biol. Plant. 50, 597-602 (2006). 
12. Gazanchian, A., Hajheidari, M., Sima, N. K. \& Salekdeh, G. H. Proteome response of Elymus elongatum to severe water stress and recovery. J. Exp. Bot. 58, 291-300 (2007).

13. Kottapalli, K. R. et al. Physiology and proteomics of the water-deficit stress response in three contrasting peanut genotypes. Plant Cell Environ. 32, 380-407 (2009).

14. Ford, K. L., Cassin, C. \& Bacic, A. Quantitative proteomic analysis of wheat cultivars with differing drought tolerance. Front. Plant Sci. 2, 44 (2011)

15. Mirzaei, M. et al. Manipulating root water supply elicits major shifts in the shoot proteome. J. Prot. Res. 7, 517-26 (2014).

16. Faghani, E. et al. Comparative physiology and proteomic analysis of two wheat genotypes contrasting in drought tolerance. J. Prot. 114, 1-15 (2015).

17. Robinson, S. P. \& Portis, A. R. Involvement of stromal ATP in the light activation of ribulose-1, 5-bisphosphate carboxylase/ oxygenase in intact isolated chloroplasts. Plant Physiol. 86, 293-298 (1988).

18. Sharkey, T. D. \& Seemann, J. R. Mild water stress effects on carbon-reduction-cycle intermediates, ribulose bis-phosphate carboxylase activity \& spatial homogeneity of photosynthesis in intact leaves. Plant Physiol. 89, 1060-1065 (1989).

19. Graan, T. \& Boyer, J. S. Very high $\mathrm{CO}_{2}$ partially restores photosynthesis in sunflower at low water potentials. Planta 181, 378-384 (1990).

20. Bota, J., Medrano, H. \& Flexas, J. Is photosynthesis limited by decreased Rubisco activity and RuBP content under progressive water stress? New Phytol. 162, 671-681 (2004).

21. Toivonen, P. \& Vidaver, W. Variable chlorophyll a fluorescence and $\mathrm{CO}_{2}$ uptake in water stressed white spruce seedlings. Plant Physiol. 86, 744-748 (1988).

22. Alberte, R. S., Fiscus, E. L. \& Naylor, A. W. The effects of water stress on the development of the photosynthetic apparatus in greening leaves. Plant Physiol. 55, 317-321 (1975).

23. He, J. X., Wang, J. \& Liang, H. G. Effects of water-stress on photochemical function and protein-metabolism of photosystem-II in wheat leaves. Physiol. Plant. 93, 771-777 (1995).

24. Giardi, M. T. et al. Long-term drought stress induces structural and functional reorganization of photosystem II. Planta 199, $118-125$ (1996).

25. Zhou, Y., Lam, H. M. \& Zhang, J. Inhibition of photosynthesis and energy dissipation induced by water and high light stresses in rice. J. Exp. Bot. 58, 1207-1217 (2007).

26. Mehler, A. H. Studies on reactions of illuminated chloroplasts: I. Mechanism of the reduction of oxygen and other Hill reagents. Archs. Biochem. Biophys. 33, 65-77 (1951).

27. Miller, G., Suzuki, N., Ciftci-Yilmaz, S. \& Mittler, R. Reactive oxygen species homeostasis and signaling during drought and salinity stresses. Plant Cell Environ. 33, 453-467 (2010).

28. Chakraborty, N. \& Tripathy, B. C. Involvement of singlet oxygen in 5-aminolevulinic acid induced photodynamic damage of cucumber (Cucumis sativus L.) chloroplasts. Plant Physiol. 98, 7-11 (1992).

29. Murata, N., Allakhverdiev, S. I. \& Nishiyama, Y. The mechanism of photoinhibition in vivo: re-evaluation of the roles of catalase, $\alpha$-tocopherol, non-photochemical quenching, and electron transport. Biochim. Biophys. Acta 1817, 1127-1133 (2012).

30. Schmitt, F. J. et al. Reactive oxygen species: re-evaluation of generation, monitoring and role in stress-signaling in phototrophic organisms. Biochim Biophy Acta 1837, 835-84 (2014).

31. Tripathy, B. C., Mohapatra, A. \& Gupta, I. Impairment of the photosynthetic apparatus by oxidative stress induced by photosensitization reaction of protoporphyrin IX. Biochim. Biophys. Acta 1767, 860-868 (2007).

32. Santel, H. J. \& Apel, K. The protochlorophyllide holochrome of barley (Hordeum vulgare L.): the effect of light on the NADPH: protochlorophyllide oxidoreductase. FEBS J. 120, 95-103 (1981).

33. Dalal, V. K. \& Tripathy, B. C. Modulation of chlorophyll biosynthesis by water stress in rice seedlings during chloroplast biogenesis. Plant Cell Environ. 35, 1685-1703 (2012).

34. Mimuro, M. \& Tanaka, A. The in vivo and in vitro reconstitution of pigment-protein complexes \& its implication in acquiring a new system. Photosynth. Res. 81, 129-137 (2004).

35. Michel, B. E. \& Kaufmann, M. R. The osmotic potential of polyethylene glycol 6000. Plant Physiol. 51, 914 (1973).

36. Chezen, O., Hartwig, W. \& Newman, P. M. The different effects of PEG-6000 and NaCl on leaf development are associated with differential inhibition of root water transport. Plant Cell 18, 727-735 (1995).

37. Genty, B., Briantais, J. M. \& Baker, N. R. The relationship between the quantum yield of photosynthetic electron transport and quenching of chlorophyll fluorescence. Biochim. Biophys. Acta 990, 87-92 (1989).

38. Govindjee. Sixty-three years since Kautsky: chlorophyll a fluorescence. Aust. J. Plant Physiol. 22, 131-160 (1995).

39. Govindjee, W. \& Prezelin, D. B.B. \& Sweeney, B.M. Chlorophyll a fluorescence of Gonyaulax polydera grown on a light-dark cycle and after transfer to constant light. Photochem. Photobiol. 30, 405-411 (1979).

40. Sayre, R. T. \& Cheniae, G. M. Studies on the reconstitution of $\mathrm{O}_{2}$-evolution in chloroplasts. Plant Physiol. 69, 1084-1095 (1982).

41. Hodges DeLong, J. M., Forney, C. F. \& Prange, R. K. Improving the thiobarbituric acid-reactive-substances assay for estimating lipid peroxidation in plant tissues containing anthocyanin and other interfering compounds. Planta 207, 604-611 (1999).

42. Shibata, K. Spectroscopic studies on chlorophyll formation in intact leaves. J. Biochem. 44, 147-173 (1957).

43. Bellemare, G., Bartlett, S. G. \& Chua, N. H. Biosynthesis of chlorophyll a/b-binding polypeptides in wild type and the chlorina $\mathrm{f} 2$ mutant of barley. J. Biol. Chem. 257, 7762-7767 (1982).

44. Paulsen, H., Finkenzeller, B. \& Kühlein, N. Pigments induce folding of light-harvesting chlorophyll a/b-binding protein. Eur. J. Biochem. 215, 809-816 (1993).

45. Schlicke, H. et al. Induced deactivation of genes encoding chlorophyll biosynthesis enzymes disentangles tetrapyrrole-mediated retrograde signaling. Mol. Plant 7, 1211-1227 (2014).

46. Busch, A. W. \& Montgomery, B. L. Interdependence of tetrapyrrole metabolism, the generation of oxidative stress and the mitigative oxidative stress response. Redox Biol. 4, 260-271 (2015).

47. Nishiyama, Y. et al. Oxidative stress inhibits the repair of photodamage to the photosynthetic machinery. EMBO J. 20, 5587-5594 (2001).

48. Allakhverdiev, S. I. et al. Systematic analysis of the relation of electron transport and ATP synthesis to the photodamage and repair of photosystem II in Synechocystis. Plant Physiol. 137, 263-273 (2005).

49. Dall'Osto, L., Cazzaniga, S., Havaux, M. \& Bassi, S. Enhanced photoprotection by protein-bound vs free xanthophyll pools: a comparative analysis of chlorophyll b and xanthophyll biosynthesis mutants. Mol. Plant 3, 576-593 (2010).

50. Biswal, A. K. et al. Light intensity-dependent modulation of chlorophyll b biosynthesis and photosynthesis by overexpression of chlorophyllide a oxygenase (CAO) in tobacco. Plant Physiol. 159, 433-449 (2012).

51. Tambussi, E. A., Bartoli, C. G., Beltrano, J., Guiamet, J. J. \& Araus, J. L. Oxidative damage to thylakoid proteins in water-stressed leaves of wheat (Triticum aestium). Plant Physiol. 108, 398-404 (2000).

52. Špundová, M. et al. Ultra-structural and functional changes in the chloroplasts of deteched barley leaves senesing under dark and light conditions. J. Plant Physiol. 160, 1051-1058 (2003).

53. Demmig-Adams, B. \& Adams, W. W. III Xanthophyll cycle and light stress in nature: uniform response to excess direct sunlight among higher plant species. Planta 198, 460-470 (1996).

54. Bricker, T. M., Roose, J. L., Fagerlund, R. D., Frankel, L. K. \& Eaton-Rye, J. J. The extrinsic proteins of Photosystem II. Biochim. Biophys. Acta 1817, 121-142 (2012). 
55. Dwyer, S. A. et al. Antisense reductions in the PsbO protein of photosystem II leads to decreased quantum yield but similar maximal photosynthetic rates. J. Exp. Bot. 63, 4781-4795 (2012).

56. Kanazawa, A. \& Kramer, D. M. In vivo modulation of nonphotochemical quenching (NPQ) by regulation of chloroplast ATP synthase. Proc. Natl. Acad. Sci. USA 99, 12789-12794 (2002).

57. Mullet, J. E., Burke, J. J. \& Arnezen, C. J. Chlorophyll proteins of photosystem I. Plant Physiol. 65, 814-822 (1980).

58. Kuang, T. Y., Argyroudi-Akoyunoglou, J. H., Nakatani, H. Y., Watson, J. \& Arntzen, C. J. The origin of the long-wavelength fluorescence emission band (77 degrees K) from photosystem I. Archs. Biochem. Biophys. 235, 618-627 (1984).

59. Briantais, J. M., Krause, G. H., Vernotte, C. \& Weis, E. Chlorophyll a fluorescence of higher plants, chloroplasts and leaves in Light Emission by Plants and Bacteria (eds Govindjee, Amesz, J. \& Fork, D. C.) 539-583 (Academic Press, 1986).

60. Williams, R. S., Allen, J. F., Brain, A. P. R. \& Ellis, R. J. Effect of $\mathrm{Mg}^{2+}$ on excitation energy transfer between LHCII and LHCI in a chlorophyll-protein complex. FEBS Lett. 225, 59-66 (1987).

61. Rubin, B. T., Chow, W. S. \& Barber, J. Experimental and theoretical considerations of mechanisms controlling cation effects on thylakoid membrane stacking and chlorophyll fluorescence. Biochim. Biophys. Acta 634, 174-190 (1981)

62. Kaňa, R. \& Govindjee. Role of ions in the regulation of light harvesting. Front. Plant Sci. 7, 1849 (2016)

63. Medrano, H., Parry, M. A. J., Socias, X. \& Lawlor, D. W. Long term water stress inactivates Rubisco in subterranean clover. Ann. App. Biol. 131, 491-501 (1997).

64. Tripathy, B. C. \& Oelmüller, R. Reactive oxygen species generation and signaling in plants. Plant Sig. Behav. 7, 1621-1633 (2012).

65. Zivcak, M. et al. Photosynthetic electron transport and specific photoprotective responses in wheat leaves under drought stress. Photosynth. Res. 117, 529-546 (2013).

66. Murashige, T. \& Skoog, F. A revised medium for rapid growth and bio-assays with tobacco tissue cultures. Plant Physiol. 15, 473-497 (1962).

67. Porra, R. J., Thompson, W. A. \& Kriedemann, P. E. Determination of accurate coefficients and simultaneous equations for assaying chlorophylls $\mathrm{a}$ and $\mathrm{b}$ extracted with four different solvents: verification of the concentration of chlorophyll standards by atomic absorption spectroscopy. Biochim. Biophys. Acta 975, 384-394 (1989).

68. Tripathy, B. C. \& Chakraborty, N. 5-aminolevulinic acid induced photodynamic damage of the photosynthetic electron transport chain of cucumber (Cucumis sativus L) cotyledons. Plant Physiol. 96, 761-767 (1991).

69. Tripathy, B. C. \& Mohanty, P. Zinc-inhibited electron transport of photosynthesis in isolated barley chloroplasts. Plant Physiol. 66, $1174-1178(1980)$.

70. Graham, R. C. \& Karnovsky, M. J. The early stages of absorption of injected horseradish peroxidase in the proximal tubules of mouse kidney: Ultrastructural cytochemistry by a new technique. J. Histochem. Cytochem. 14, 291-302 (1966).

71. Stirbet, A. \& Govindjee. On the relation between the Kautsky effect (chlorophyll a fluorescence induction) and photosystem II: Basis and applications of the OJIP fluorescence transient. J. Photochem. Photobiol. B Biol. 104, 236-257 (2011).

72. Papageorgiou, G. C. \& Govindjee (eds) Chlorophyll $a$ Fluorescence: A Signature of Photosynthesis. Advances in Photosynthesis and Respiration, 19. (Springer, Dordrecht, 2004).

73. Bradford, M. M. A rapid and sensitive method for the quantification of microgram quantities of protein utilizing the principle of protein-dye binding. Annal. Biochem. 72, 248-254 (1976).

74. Velikova, V., Yordanov, I. \& Edreva, A. Oxidative stress and some antioxidant systems in acid rain-treated bean plants: protective role of exogenous poly-amines. Plant Sci. 151, 59-66 (2000).

75. Kim, S. T., Cho, K. S., Jang, Y. S. \& Kang, K. Y. Two-dimensional electrophoretic analysis of rice proteins by polyethyleneglycol fractionation for protein arrays. Electrophoresis 22, 2103-2109 (2001).

76. Wang, Z. et al. Mass spectrometric analysis of protein markers for ovarian cancer. Clin. Chem. 50, 1939-1942 (2004).

77. Narsai, R. et al. Rice DB: An Oryza Information Portal linking annotation, sub-cellular location, function, expression, regulation and evolutionary information for rice and Arabidopsis. Plant J. 76, 1057-1073 (2013).

\section{Acknowledgements}

This work was supported by a J.C. Bose Fellowship from the Department of Science and Technology, Govt. of India to B.C.T. Authors thank A Stirbet and Govindjee, Professor Emeritus, Biochemistry, Biophysics and Plant Biology, UIUC, Urbana, IL for critically evaluating the scientific content and editing the English language of the manuscript.

\section{Author Contributions}

B.C.T. designed the experiments and V.K.D. conducted all the experiments. Manuscript was written by V.K.D. and B.C.T.

\section{Additional Information}

Supplementary information accompanies this paper at https://doi.org/10.1038/s41598-017-14419-4.

Competing Interests: The authors declare that they have no competing interests.

Publisher's note: Springer Nature remains neutral with regard to jurisdictional claims in published maps and institutional affiliations.

Open Access This article is licensed under a Creative Commons Attribution 4.0 International

License, which permits use, sharing, adaptation, distribution and reproduction in any medium or format, as long as you give appropriate credit to the original author(s) and the source, provide a link to the Creative Commons license, and indicate if changes were made. The images or other third party material in this article are included in the article's Creative Commons license, unless indicated otherwise in a credit line to the material. If material is not included in the article's Creative Commons license and your intended use is not permitted by statutory regulation or exceeds the permitted use, you will need to obtain permission directly from the copyright holder. To view a copy of this license, visit http://creativecommons.org/licenses/by/4.0/.

(C) The Author(s) 2017 